\title{
Biotic stoichiometric controls on the deep ocean N:P ratio*
}

\author{
T. M. Lenton ${ }^{1}$ and C. A. Klausmeier ${ }^{2}$ \\ ${ }^{1}$ School of Environmental Sciences, University of East Anglia, Norwich NR4 7TJ, UK \\ ${ }^{2}$ W. K. Kellogg Biological Station, Michigan State University, Hickory Corners, MI 49060, USA \\ *Invited contribution by T. M. Lenton, one of the EGU Outstanding Young Scientist Award winners 2006
}

Received: 1 February 2007 - Published in Biogeosciences Discuss.: 8 February 2007

Revised: 23 May 2007 - Accepted: 6 June 2007 - Published: 20 June 2007

\begin{abstract}
We re-examine what controls the deep ocean N:P ratio in the light of recent findings that the $\mathrm{C}: \mathrm{N}: \mathrm{P}$ stoichiometry of phytoplankton varies with growth rate, nutrient and light limitation, species and phylum, and that $\mathrm{N}_{2}$-fixation may be limited by $\mathrm{Fe}$, temperature and/or light in large parts of the world ocean. In particular, we assess whether a systematic change in phytoplankton stoichiometry can alter the deep ocean N:P ratio. To do this we adapt recent models to include non-Redfieldian stoichiometry of phytoplankton and restriction of $\mathrm{N}_{2}$-fixers to a fraction of the surface ocean. We show that a systematic change in phytoplankton $\mathrm{C}: \mathrm{N}: \mathrm{P}$ can alter the concentrations of $\mathrm{NO}_{3}$ and $\mathrm{PO}_{4}$ in the deep ocean but cannot greatly alter their ratio, unless it also alters the $\mathrm{N}: \mathrm{P}$ threshold for $\mathrm{N}_{2}$-fixation. This occurs if competitive dynamics set the $\mathrm{N}: \mathrm{P}$ threshold for $\mathrm{N}_{2}$-fixation, in which case it remains close to the $\mathrm{N}: \mathrm{P}$ requirement of non-fixers (rather than that of $\mathrm{N}_{2}$-fixers) and consequently so does the deep ocean $\mathrm{N}: \mathrm{P}$ ratio. Then, even if $\mathrm{N}_{2}$-fixers are restricted to a fraction of the surface ocean, they reach higher densities there, minimising variations in deep ocean N:P. Theoretical limits on the $\mathrm{N}: \mathrm{P}$ requirements of phytoplankton suggest that whilst the deep ocean has been well oxygenated (i.e. since the Neoproterozoic, with the possible exception of Oceanic Anoxic Events), its N:P ratio is unlikely to have varied by more than a factor of two in either direction. Within these bounds, evolutionary changes in phytoplankton composition, and increased phosphorus weathering due to the biological colonisation of the land surface, are predicted to have driven long-term changes in ocean composition.
\end{abstract}

Correspondence to: T. M. Lenton

(t.lenton@uea.ac.uk)

\section{Introduction}

There is a well-known correspondence between the average proportions of $\mathrm{N}$ and $\mathrm{P}$ in marine organic matter - the "Redfield ratio" of $\mathrm{N}: \mathrm{P} \sim 16$ - and the composition of the deep ocean with $\mathrm{N}: \mathrm{P} \sim 15$. Redfield (1934) suggested that an explanation "... may be sought in the activities of those bacteria which form nitrogenous compounds or liberate nitrogen in the course of the decomposition of organic matter" intuiting that "... in a world populated by organisms of these two types the relative proportion of phosphate and nitrate must tend to approach that characteristic of protoplasm in general..." In his later work, Redfield (1958) proposed that: "When living in an environment containing a deficiency of nitrate relative to phosphate, the growth and assimilation of the nitrogenfixing organisms might tend continually to bring the proportions of nitrogen and phosphorus nearer to that characteristic of their own substance." Subsequent workers (Broecker and Peng, 1982; Tyrrell, 1999; Lenton and Watson, 2000) have expressed the mechanism in terms of competition between $\mathrm{N}_{2}$-fixing organisms that are selected when $\mathrm{N}: \mathrm{P}<16$ and nonfixers that out-compete them when $\mathrm{N}: \mathrm{P}>16$. This mechanism assumes that under $\mathrm{P}$-limiting conditions $\mathrm{N}_{2}$-fixers have a lower growth rate than non-fixers, because of the high energy cost of $\mathrm{N}_{2}$-fixation, whilst under sufficiently $\mathrm{N}$-limiting conditions $\mathrm{N}_{2}$-fixers out-compete non-fixers.

The canonical value of $\sim 16$ for the N:P Redfield ratio represents an average for today's phytoplankton. It has long been known that the Redfield ratios of phytoplankton vary with growth rate (Goldman et al., 1979) and light regime (Goldman, 1986). Nutrient replete phytoplankton cultures (with consequently high growth rates) have a mean N:P of 10.1 across 34 studies, in contrast to marine particulate matter with a mean N:P of 16.4 across 27 studies (Geider and La Roche, 2002). It was thought that $\mathrm{N}: \mathrm{P} \sim 16$ might represent some kind of optimum for phytoplankton, but no theoretical basis has yet been found for this (Klausmeier et al., 2004).

Published by Copernicus Publications on behalf of the European Geosciences Union. 
Instead, a model predicts that the optimum composition of phytoplankton under exponential growth is 8.2 , whilst under light limitation it is 35.8 , nitrogen limitation 37.4, and phosphorus limitation 45.0 (Klausmeier et al., 2004). Furthermore, different phyla or super-families of differing antiquity have different N:P, with older "greens" having higher $\mathrm{N}: \mathrm{P}$ than younger "reds" (Quigg et al., 2003). This raises the question (Falkowski and Davis, 2004; Arrigo, 2005): Would a systematic shift in the Redfield ratios alter deep ocean composition?

The question provokes a deeper one: What sets the deep ocean N:P ratio? Some authors still make statements, which can be traced back to Redfield (1934), to the effect that the ratio of major nutrients $\mathrm{N}: \mathrm{P} \sim 15$ in the deep ocean directly reflects the average Redfield ratio $(\mathrm{N}: \mathrm{P} \sim 16)$ of sinking organic matter being remineralised in the water column. However, the cycle of uptake in the surface ocean and remineralisation at depth only redistributes $\mathrm{NO}_{3}$ and $\mathrm{PO}_{4}$, it cannot directly alter their absolute or relative amounts in the ocean as a whole, which depend on net input to or removal from the ocean. The ocean mixing time $\left(<10^{3} \mathrm{yr}\right)$ is shorter than the residence time of $\mathrm{NO}_{3}\left(\sim 3 \times 10^{3} \mathrm{yr}\right)$ (Codispoti, 1995; Lenton and Watson, 2000), which is in turn shorter than that of $\mathrm{PO}_{4}\left(\sim 1.8 \times 10^{4} \mathrm{yr}\right)$ (Ruttenberg, 1993; Lenton and Watson, 2000). Hence mixing tends to homogenize the concentrations of both nutrients. Furthermore, we can consider a timescale over which $\mathrm{PO}_{4}$ is relatively constant but $\mathrm{NO}_{3}$ can vary due to imbalances of input (primarily $\mathrm{N}_{2}$-fixation) and output (primarily denitrification) processes. The essence of Redfield's mechanism is that $\mathrm{N}_{2}$-fixation responds to any deficit of $\mathrm{NO}_{3}$ relative to the $\mathrm{N}$ :P requirement of average phytoplankton (non-fixers), whilst denitrification tends to continually remove $\mathrm{NO}_{3}$ and thus maintain a small $\mathrm{N}$ :P deficit and corresponding population of $\mathrm{N}_{2}$-fixers.

Both $\mathrm{N}_{2}$-fixation and denitrification processes need some elaboration in the light of recent discoveries. On the input side, although $\mathrm{N}_{2}$-fixation is sometimes P-limited and suppressed by $\mathrm{N}$-addition, there is also evidence for Fe-limitation (Berman-Frank et al., 2001; Mills et al., 2004), temperature-limitation (Breitbarth et al., 2007), lightlimitation (Hood et al., 2004) and $\mathrm{P}$ and $\mathrm{Fe}$ co-limitation (Mills et al., 2004) of $\mathrm{N}_{2}$-fixers. This raises the question: Given that $\mathrm{N}_{2}$-fixers may be limited to restricted areas of the world ocean, can they still regulate deep ocean $\mathrm{N}: \mathrm{P}$ ? It has recently been inferred that nitrogen inputs and losses in the ocean are spatially coupled (Deutsch et al., 2007), which may alleviate the problem somewhat. On the output side, anaerobic ammonium oxidation ("anammox"; $\mathrm{NH}_{4}^{+}+\mathrm{NO}_{2}^{-} \rightarrow \mathrm{N}_{2}+2 \mathrm{H}_{2} \mathrm{O}$ ), in the ocean water column and sediments, has been found to be responsible for significant removal (up to 30-50\%) of fixed nitrogen (Dalsgaard et al., 2003; Kuypers et al., 2003) and thus contributes to lowering deep ocean N:P. However, both processes occur under anaerobic conditions, and the nitrite $\left(\mathrm{NO}_{2}^{-}\right)$used in the anammox reaction may be supplied by denitrification (of $\mathrm{NO}_{3}$ ). Hence there is no qualitative change to Redfield's mechanism and in the remainder of this article we take "denitrification" to also include anammox.

Our aims in this paper are to elucidate the controls on the deep ocean N:P ratio by adapting two existing, simple models (Tyrrell, 1999; Lenton and Watson, 2000) and conducting a series of "What if...?" thought experiments. Section 2 introduces the models and Sect. 3 presents the results. First we examine what controls deep ocean N:P by decoupling the $\mathrm{N}: \mathrm{P}$ ratio of phytoplankton from the $\mathrm{N}: \mathrm{P}$ threshold that triggers $\mathrm{N}_{2}$-fixation, and varying each independently. Having established which exerts the greatest control on deep ocean $\mathrm{N}: \mathrm{P}$, we couple these ratios through the common assumption that competitive dynamics set the $\mathrm{N}: \mathrm{P}$ threshold for $\mathrm{N}_{2}-$ fixation, and we maintain this assumption for the remainder of the Results. We examine the relative influences of the N:P ratios of non-fixers and of $\mathrm{N}_{2}$-fixers on the deep ocean $\mathrm{N}: \mathrm{P}$ ratio. Then we consider what happens if $\mathrm{N}_{2}$-fixers are limited to a fraction of the surface ocean. The effects of changes in the $\mathrm{N}: \mathrm{P}$ ratio of the phytoplankton (and corresponding changes in the $\mathrm{N}: \mathrm{P}$ threshold of $\mathrm{N}_{2}$-fixation) on long-term steady state deep ocean N:P are estimated. Then the effect of variations in weathering rate are examined. Finally we make an estimate of the combined effects of changes in N:P of the phytoplankton and changes in weathering. Section 4 discusses the findings and Sect. 5 concludes.

\section{Methods}

Here we introduce the two models adapted for this study (Fig. 1-2). For further explanation and justification of their formulation, including the values chosen for various constants, see Lenton and Watson (2000) (henceforth LW) and Tyrrell (1999) (henceforth TT). Those readers familiar with one or both models may skip the corresponding section(s). Both are simple box models, LW is essentially a 1-box model, TT is a 2-box model and we extend it to 3 boxes. $\mathrm{LW}$ include $\mathrm{N}, \mathrm{P}, \mathrm{C}$ and $\mathrm{O}_{2}$ cycling and concentrate on the feedback mechanisms in the system, but have no explicit biological populations. TT includes $\mathrm{N}$ and $\mathrm{P}$ cycling and explicit competition between $\mathrm{N}_{2}$-fixers and non-fixers, but has no $\mathrm{C}$ or $\mathrm{O}_{2}$ cycling hence the effects of changes in $\mathrm{C}: \mathrm{P}$ or $\mathrm{C}: \mathrm{N}$ ratios cannot be addressed. Table 1 lists the key parameters varied in this study and all other model constants.

\subsection{LW model}

Lenton and Watson (2000) model (Fig. 1) reservoirs of nitrate $\left(\mathrm{NO}_{3}\right.$, actually available nitrogen) and phosphate $\left(\mathrm{PO}_{4}\right)$ expressed as deep ocean concentrations, and a reservoir of atmospheric oxygen $\left(\mathrm{O}_{2}\right)$ expressed as the concentration in water ventilating the deep ocean. Here we generalize the original model (M1) of LW to allow independent variation of the C:N and C:P Redfield ratios of new production, denoted 
Table 1. Model parameters varied in this study and all remaining model constants.

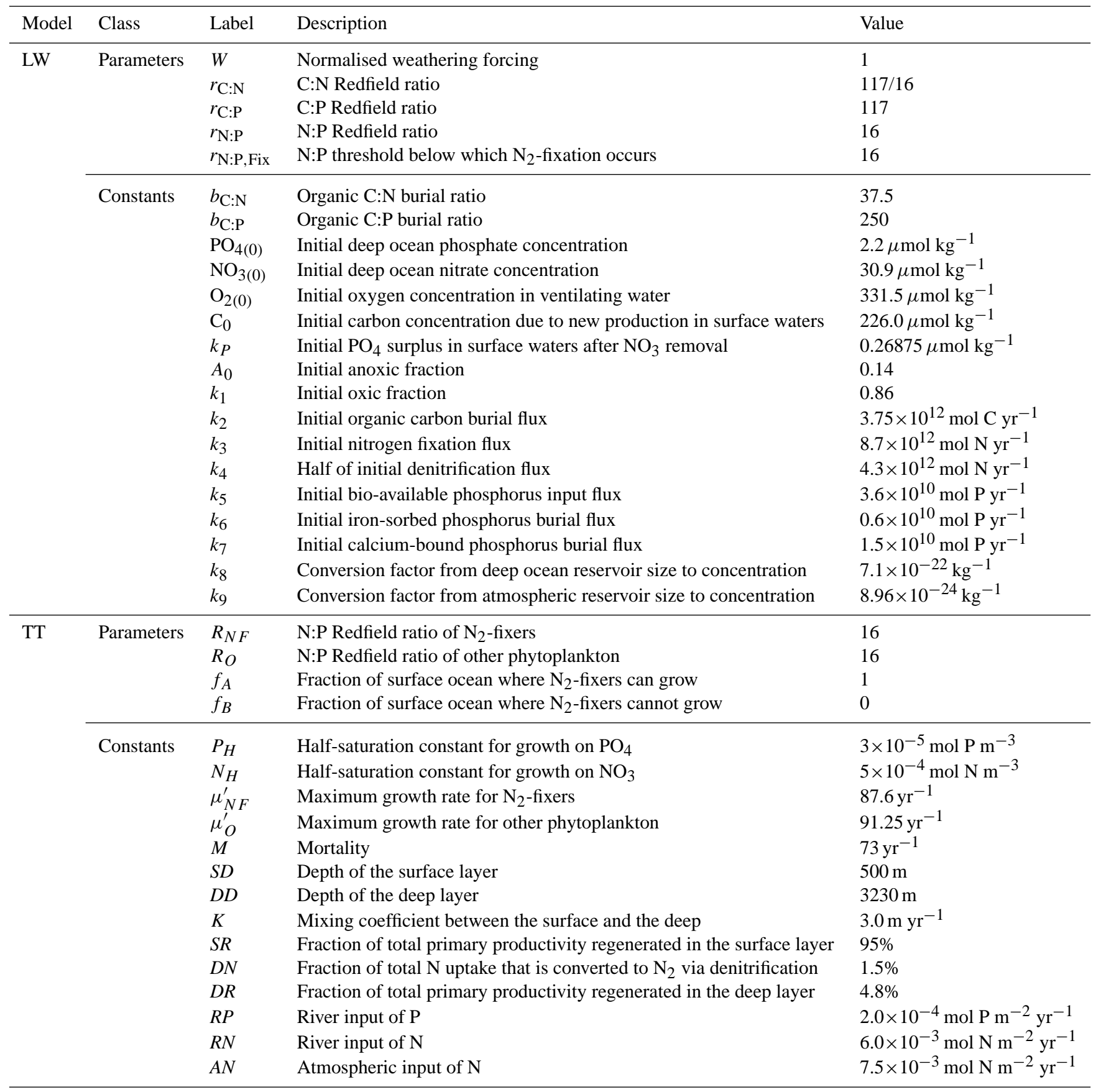

$r_{\mathrm{C}: \mathrm{N}}$ and $r_{\mathrm{C}: \mathrm{P}}$, and the $\mathrm{N}: \mathrm{P}$ threshold below which $\mathrm{N}_{2}$-fixation occurs, denoted $r_{\mathrm{N}: \mathrm{P} \text {, Fix }}$.

The limiting nutrient in water up-welled to the surface ocean is assumed to be completely used up, generating a corresponding concentration $\left(\mu \mathrm{mol} \mathrm{kg}{ }^{-1}\right)$ of carbon due to new production in the surface layer, denoted $C$ here instead of $N$ (to avoid confusion with Tyrrell's $N$ ):
$C=\min \left(r_{\mathrm{C}: \mathrm{NNO}}, \mathrm{r}_{\mathrm{C}: \mathrm{P}} \mathrm{PO}_{4}\right)$

$\mathrm{N}_{2}$-fixation (N-Fix) is assumed to depend on the deficit of $\mathrm{NO}_{3} / r_{\mathrm{N}: \mathrm{P}, \text { Fix }}$ below $\mathrm{PO}_{4}$ :

$$
F_{\mathrm{N}-\mathrm{Fix}}=\frac{k_{3}}{k_{P}}\left(\mathrm{PO}_{4}-\frac{\mathrm{NO}_{3}}{r_{\mathrm{N}: \mathrm{P}, \mathrm{Fix}}}\right)
$$




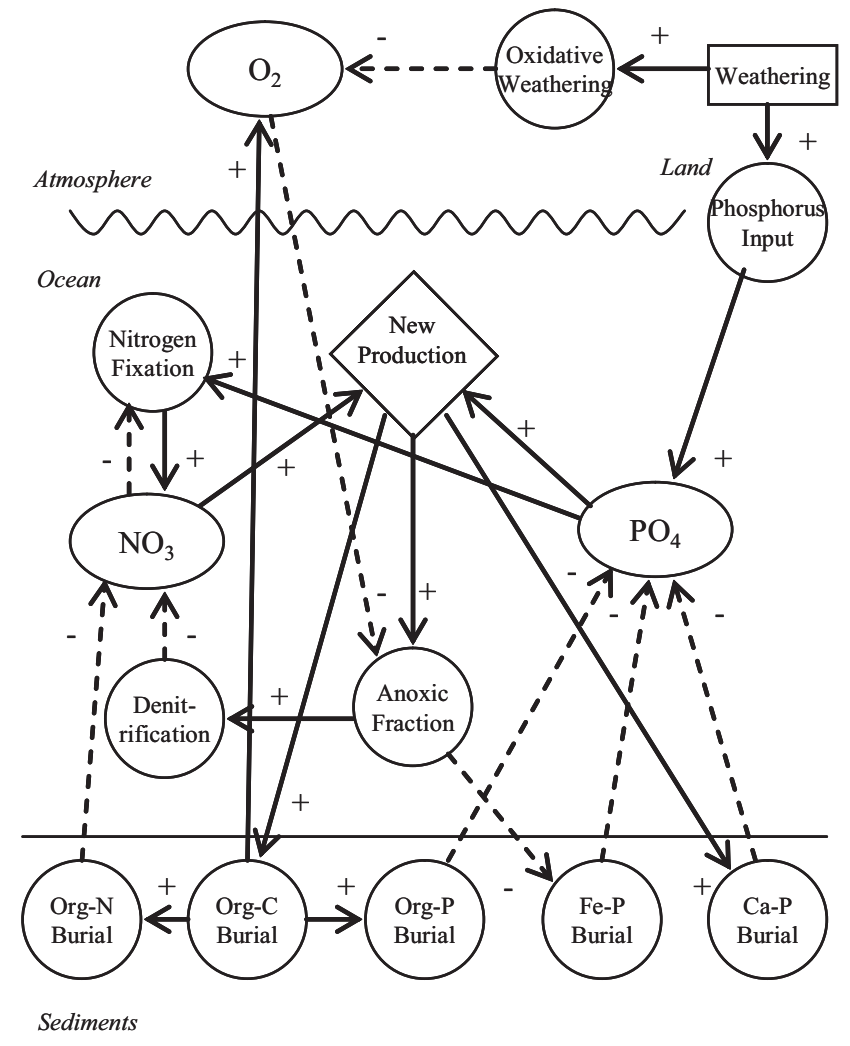

Fig. 1. Feedback diagram of the LW model where arrows indicate causal relationships. Ovals indicate reservoirs, circles indicate dependent variables, the diamond indicates a switch - new production is determined by either $\mathrm{NO}_{3}$ or $\mathrm{PO}_{4}-$ and the rectangle indicates the single input parameter, weathering. A solid arrow with a plus sign indicates a direct relationship, e.g. increased nitrogen fixation increases $\mathrm{NO}_{3}$. A dashed arrow with a minus sign indicates an inverse relationship, e.g. increased $\mathrm{NO}_{3}$ decreases nitrogen fixation. In this example, a negative feedback loop is closed. All closed loops of arrows that can be traced around the diagram represent feedbacks. If there are an odd number of inverse relationships in a loop it is a negative feedback, whereas those containing none or an even number are positive feedbacks.

where $F$ denotes a flux. All constants are retained including the initial $\mathrm{N}_{2}$-fixation flux $k_{3}=8.7 \times 10^{12} \mathrm{~mol} \mathrm{~N} \mathrm{yr}^{-1}$ and the initial average deep ocean nutrient concentrations of $\mathrm{PO}_{4(0)}=2.2 \mu \mathrm{mol} \mathrm{kg}{ }^{-1}$ and $\mathrm{NO}_{3(0)}=30.9 \mu \mathrm{mol} \mathrm{kg}^{-1}$ from World Ocean Atlas data. The derived constant $k_{P}=\mathrm{PO}_{4(0)}-$ $\mathrm{NO}_{3(0)} / 16=0.26875 \mu \mathrm{mol} \mathrm{kg}^{-1}$ represents the average surplus $\mathrm{PO}_{4}$ remaining in surface waters after $\mathrm{NO}_{3}$ has been removed by new production. $\mathrm{N}_{2}$-fixation provides negative feedback on nitrate that tends to couple it to phosphate, e.g. increased $\mathrm{NO}_{3}$ suppresses $\mathrm{N}_{2}$-fixation, counteracting the initial change.

The anoxic fraction of the ocean $(A)$ depends on the balance of oxygen supply via ocean mixing and oxygen demand due to respiration of sinking new production:

$A=1-k_{1} \frac{\mathrm{O}_{2}}{\mathrm{O}_{2(0)}} \frac{C_{0}}{C}$

The initial oxic fraction $k_{1}=0.86$ and the initial anoxic fraction $A_{0}=0.14$ are derived from data for the present ocean. The initial oxygen concentration for water ventilating the deep ocean $\mathrm{O}_{2(0)}=331.5 \mu \mathrm{mol} \mathrm{kg}^{-1}$ is based on a temperature of $2^{\circ} \mathrm{C}$. The initial average carbon concentration due to new production in surface waters $C_{0}=226.0 \mu \mathrm{mol} \mathrm{kg}^{-1}$ is derived from $\mathrm{NO}_{3(0)}$ and the present value of $r_{\mathrm{C}: \mathrm{N}}$.

Denitrification (De-N) comprises a fixed sedimentary flux and a variable water column flux that depends on anoxia:

$F_{\text {De-N }}=k_{4}\left(1+\frac{A}{A_{0}}\right)$

where $k_{4}=4.3 \times 10^{12} \mathrm{~mol} \mathrm{~N} \mathrm{yr}^{-1}$ is the initial size of each flux. The dependence of water column denitrification on anoxia provides negative feedback on nitrate that tends to couple nitrate to oxygen, e.g. increased $\mathrm{NO}_{3}$ increases new production, anoxia, and denitrification, thus counteracting the initial change.

A further minor sink of nitrate is organic nitrogen (Org-N) burial, which occurs with the burial of organic carbon and a $\mathrm{C}: \mathrm{N}$ burial ratio $b_{\mathrm{C}: \mathrm{N}}=37.5$ :

$F_{\text {Org }-\mathrm{N}}=\frac{k_{2}}{b_{\mathrm{C}: \mathrm{N}}}\left(\frac{C}{C_{0}}\right)^{2}$

where the initial organic carbon burial flux $k_{2}=3.75 \times 10^{12} \mathrm{~mol} \mathrm{Cyr}^{-1}$, hence organic nitrogen burial is initially $0.1 \times 10^{12} \mathrm{~mol} \mathrm{Nyr}^{-1}$. Organic nitrogen burial provides a small additional negative feedback on nitrate, e.g. increased $\mathrm{NO}_{3}$ increases new production and Org-N burial, thus counteracting the initial change.

The overall rate of change of nitrate is given by:

$\frac{d \mathrm{NO}_{3}}{d t}=k_{8}\left(F_{\mathrm{N}-\mathrm{Fix}}-F_{\mathrm{De}-\mathrm{N}}-F_{\mathrm{Org}-\mathrm{N}}\right)$

where $k_{8}=7.1 \times 10^{-22} \mathrm{~kg}^{-1}$ converts from reservoir size in mol to average concentration. The overall balance of feedbacks is such that nitrate tracks any variations in phosphate.

Normalized weathering, $W$, represents the only external forcing parameter for the model (i.e. $W=1$ at present day). Weathering drives phosphorus input to the ocean (P-in), via rivers:

$F_{\mathrm{P}-\text { in }}=k_{5} W$

with initial flux $k_{5}=3.6 \times 10^{10} \mathrm{~mol} \mathrm{Pyr}^{-1}$. Phosphorus is removed from the ocean via burial in sediments, which occurs in three main forms:

Burial of phosphorus with iron oxides (Fe-P) is initially $k_{6}=0.6 \times 10^{10} \mathrm{~mol} \mathrm{Pyr}^{-1}$ and is inversely dependent on anoxia:

$F_{\mathrm{Fe}-\mathrm{P}}=\frac{k_{6}}{k_{1}}(1-A)$ 
Nitrogen

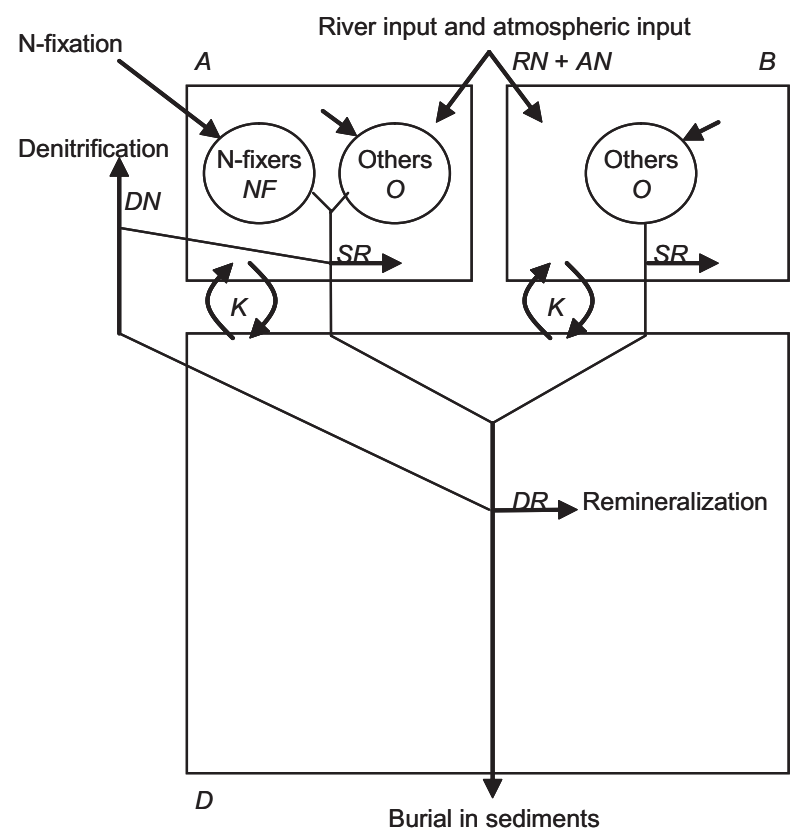

Phosphorus

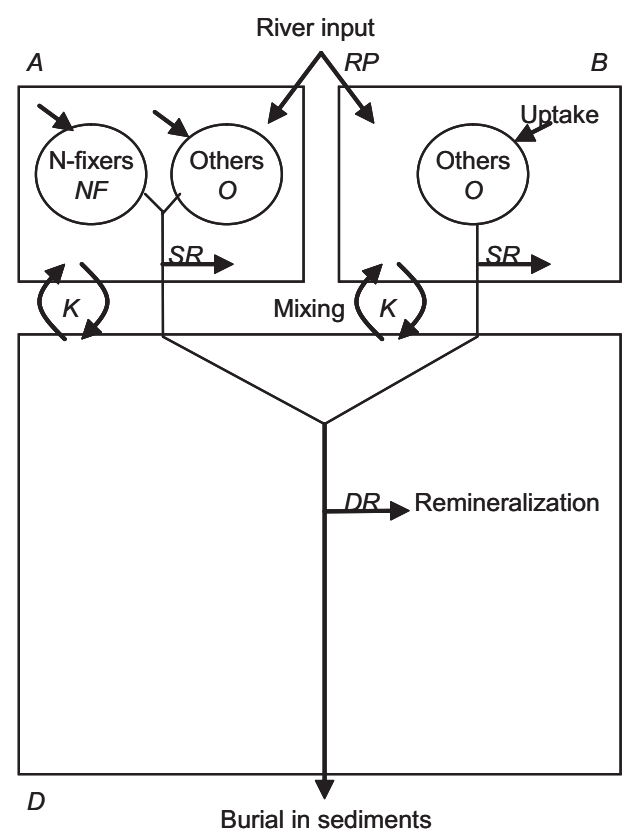

Fig. 2. Schematics of the nitrogen and phosphorus cycles in the extended TT model, where arrows indicate fluxes. The model has two surface ocean boxes $(A, B)$ and a deep ocean box $(D)$. Within box $A$ there are populations of nitrogen fixers and other phytoplankton. Within box $B$ there are only other phytoplankton. Where possible, fluxes are labelled and model variables and constants are indicated in italics. Mixing $(K)$ occurs between each surface box and the deep box but not between the two surface boxes. $\mathrm{N}$ enters the surface boxes from rivers $(R N)$ and atmospheric deposition $(A N)$. $\mathrm{P}$ enters from rivers $(R P)$. Biological uptake of nutrient is indicated by an arrow from within a surface box to a population. $\mathrm{N}$ is also fixed from outside the system directly into the $\mathrm{N}_{2}$-fixers. Mortality is represented by lines leaving the populations, forming sinking fluxes of nutrients. For both nutrients, a fraction $(S R)$ of the sinking flux is remineralised in the surface layer and a fraction $(S D)$ in the deep box. For $\mathrm{N}$, a fraction $(D N)$ is also lost by denitrification. The remaining sinking fluxes of nutrients leave the system as burial in sediments.

This provides a positive feedback on phosphate, e.g. increased $\mathrm{PO}_{4}$ tends to increase $\mathrm{NO}_{3}$, new production and anoxia, decreasing Fe-P burial and tending to further increase $\mathrm{PO}_{4}$.

Organic phosphorus (Org-P) burial is initially $1.5 \times 10^{10} \mathrm{molPyr}^{-1}$ and occurs with the burial of organic carbon in a C:P burial ratio $b_{\mathrm{C}: \mathrm{P}}=250$ :

$F_{\text {Org-P }}=\frac{k_{2}}{b_{\mathrm{C}: \mathrm{P}}}\left(\frac{C}{C_{0}}\right)^{2}$

The dependence on new production provides negative feedback on phosphate, e.g. increased $\mathrm{PO}_{4}$ tends to increase $\mathrm{NO}_{3}$, new production and Org-P burial, thus counteracting the initial change.

Calcium-bound (Ca-P) phosphorus burial is also initially $k_{7}=1.5 \times 10^{10} \mathrm{~mol} \mathrm{Pyr}^{-1}$ and is largely authigenic (it forms in sediments). The phosphorus buried as $\mathrm{Ca}-\mathrm{P}$ is supplied via new production hence it has the same functional dependence on new production as Org-P burial:

$F_{\mathrm{Ca}-\mathrm{P}}=k_{7}\left(\frac{C}{C_{0}}\right)^{2}$
This provides further negative feedback on phosphate.

The overall rate of change of phosphate is given by:

$\frac{d \mathrm{PO}_{4}}{d t}=k_{8}\left(F_{\mathrm{P}-\text { in }}-F_{\mathrm{Fe}-\mathrm{P}}-F_{\mathrm{Org}-\mathrm{P}}-F_{\mathrm{Ca}-\mathrm{P}}\right)$

The overall feedback is negative tending to buffer variations in phosphate, e.g. those driven by changes in weathering. This is because feedbacks on Org-P and Ca-P are both negative, they comprise $\approx 83 \%$ of the present $\mathrm{P}$ burial flux, and the functional dependence of their burial on productivity is quadratic (i.e. non-linear). In contrast, the positive feedback on Fe-P burial comprises $\approx 17 \%$ of $\mathrm{P}$ burial and has a simple inverse dependence on productivity.

Organic carbon (Org-C) burial provides the net source of atmospheric oxygen and depends quadratically on new production:

$F_{\text {Org-C }}=k_{2}\left(\frac{C}{C_{0}}\right)^{2}$

Although Org-C burial has no direct dependence on oxygen, the dependence of $\mathrm{Fe}-\mathrm{P}$ burial on anoxia provides a negative feedback on atmospheric oxygen, e.g. increased $\mathrm{O}_{2}$ 
decreases anoxia, increasing $\mathrm{Fe}-\mathrm{P}$ burial, decreasing $\mathrm{PO}_{4}$, tending to decrease new production and Org-C burial, thus counteracting the initial change.

Oxidative weathering $(\mathrm{Ox}-\mathrm{W})$ provides the net sink of atmospheric oxygen and is forced by $\mathrm{W}$ :

$F_{\mathrm{Ox}-\mathrm{W}}=k_{2} W$

All reduced material that is exposed is assumed to be oxidized, thus making oxygen consumption independent of oxygen level.

The overall rate of change of oxygen is given by:

$\frac{d \mathrm{O}_{2}}{d t}=k_{9}\left(F_{\text {Org }-\mathrm{C}}-F_{\mathrm{Ox}-\mathrm{W}}\right)$

where $k_{9}=8.96 \times 10^{-24} \mathrm{~kg}^{-1}$ converts from atmospheric oxygen reservoir size in mol to concentration dissolved in surface waters ventilating the deep ocean. Atmospheric oxygen has a much longer response time to perturbations $\left(\approx 10^{7} \mathrm{yr}\right)$ than either of the nutrient reservoirs. Hence the steady state response to variations in $W$ is achieved over a much longer timescale than the steady state response to variations in $r_{\mathrm{C}: \mathrm{N}}$, $r_{\mathrm{C}: \mathrm{P}}$ or $r_{\mathrm{N}: \mathrm{P}, \mathrm{Fix}}$, none of which affect $\mathrm{O}_{2}$.

The system was solved analytically for steady state following the method in the Appendix of LW but for an unknown limiting nutrient, yielding:

$\frac{C}{C_{0}}=W^{\frac{1}{2}}$

$\frac{\mathrm{O}_{2}}{\mathrm{O}_{2(0)}}=W^{\frac{3}{2}}$

$A=1-k_{1} W$

$\mathrm{PO}_{4}=\frac{\mathrm{NO}_{3}}{\mathrm{r}_{\mathrm{N}: \mathrm{P}, \mathrm{Fix}}}+\mathrm{k}_{\mathrm{P}}(4.025-3.025 \mathrm{~W})$

Steady state for $\mathrm{O}_{2}$ is lost when $A \rightarrow 0$, which from Eq. (17) gives an upper limit on $W=1.163$ (above this, $\mathrm{O}_{2}$ increases monotonically). From Eqs. (1) and (15):

$$
\min \left(r_{\mathrm{C}: \mathrm{N}} \mathrm{NO}_{3}, \mathrm{r}_{\mathrm{C}: \mathrm{P}} \mathrm{PO}_{4}\right)=C_{0} W^{\frac{1}{2}}
$$

which determines the value of the limiting nutrient and the other nutrient is found from Eq. (18). When $\mathrm{NO}_{3}$ is limiting:

$$
\begin{aligned}
\mathrm{NO}_{3} & =\frac{\mathrm{C}_{0} \mathrm{~W}^{\frac{1}{2}}}{\mathrm{r}_{\mathrm{C}: \mathrm{N}}} \\
\mathrm{PO}_{4} & =\frac{\mathrm{C}_{0} \mathrm{~W}^{\frac{1}{2}}}{\mathrm{r}_{\mathrm{C}: \mathrm{N}} \mathrm{r}_{\mathrm{N}: \mathrm{P}, \mathrm{Fix}}}+\mathrm{k}_{\mathrm{P}}(4.025-3.025 \mathrm{~W})
\end{aligned}
$$

When $\mathrm{PO}_{4}$ is limiting:

$\mathrm{PO}_{4}=\frac{\mathrm{C}_{0} \mathrm{~W}^{\frac{1}{2}}}{\mathrm{r}_{\mathrm{C}: \mathrm{P}}}$
$\mathrm{NO}_{3}=\mathrm{r}_{\mathrm{N}: \mathrm{P}, \mathrm{Fix}}\left(\frac{\mathrm{C}_{0} \mathrm{~W}^{\frac{1}{2}}}{\mathrm{r}_{\mathrm{C}: \mathrm{P}}}-\mathrm{k}_{\mathrm{P}}(4.025-3.025 \mathrm{~W})\right)$

LW took $r_{\mathrm{C}: \mathrm{N}}=117 / 16=7.3125$ and $r_{\mathrm{C}: \mathrm{P}}=117$ from nutrient data analysis (Anderson and Sarmiento, 1994) and assumed $r_{\mathrm{N}: \mathrm{P}, \mathrm{Fix}}=r_{\mathrm{C}: \mathrm{P}} / r_{\mathrm{C}: \mathrm{N}}=16$, hence $\mathrm{NO}_{3}$ was always limiting. This corresponds to a steady state $\mathrm{PO}_{4}=2.2 \mu \mathrm{mol} \mathrm{kg}{ }^{-1}$ and $\mathrm{NO}_{3}=30.9 \mu \mathrm{mol} \mathrm{kg}{ }^{-1}$, i.e. deep ocean $\mathrm{N}: \mathrm{P}=14.0$ (a little below observations).

\subsection{Extended TT model}

Tyrrell (1999) models nitrate and phosphate in two boxes, the surface and deep ocean, and includes explicit competition between $\mathrm{N}_{2}$-fixing and non-fixing organisms in the surface ocean. Here we extended the TT model (Fig. 2) in two ways: First, nitrogen-fixers and other phytoplankton are given different N:P stoichiometry ( $R_{N F}$ and $R_{O}$ respectively). Second, the surface layer of the ocean is split into two boxes, a fraction where nitrogen-fixers can grow $\left(f_{A}\right)$ and a fraction where they cannot $\left(f_{B}=1-f_{A}\right)$, due to limitation by e.g. iron, temperature or light. These two boxes are not directly coupled, but both exchange nutrients and dead biomass with the deep layer. The subscripts $A, B$ and $D$ refer to the two surface boxes and the deep box, respectively. $N F$ is the standing stock of $\mathrm{N}_{2}$-fixers and $O$ that of other phytoplankton. $P$ and $N$ are the concentrations of $\mathrm{PO}_{4}$ and $\mathrm{NO}_{3}$, respectively. All other symbols and parameter values are as in Tyrrell (1999).

The dynamics of each population is determined by a balance of nutrient uptake and mortality, described by:

$$
\begin{aligned}
& \frac{d N F_{A}}{d t}=\mu_{N F}^{\prime} \times \frac{P_{A}}{P_{A}+P_{H}} \times N F_{A}-M \times N F_{A} \\
& \frac{d O_{A}}{d t}=\mu_{O}^{\prime} \times \min \left(\frac{P_{A}}{P_{A}+P_{H}}, \frac{N_{A}}{N_{A}+N_{H}}\right) \times O_{A}-M \times O_{A} \\
& \frac{d O_{B}}{d t}=\mu_{O}^{\prime} \times \min \left(\frac{P_{B}}{P_{B}+P_{H}}, \frac{N_{B}}{N_{B}+N_{H}}\right) \times O_{B}-M \times O_{B}
\end{aligned}
$$

where net primary production of nitrogen fixers is limited only by $P$, following Michaelis-Menten kinetics with a halfsaturation constant, $P_{H}=3 \times 10^{-5} \mathrm{~mol} \mathrm{P} \mathrm{m}^{-3}$ and maximum growth rate, $\mu_{N F}^{\prime}=87.6 \mathrm{yr}^{-1}$. Other phytoplankton can be limited by either $N$ or $P$, with half-saturation constant for growth on $N$ of $N_{H}=5 \times 10^{-4} \mathrm{~mol} \mathrm{~N} \mathrm{~m}^{-3}$, and a higher maximum growth rate of $\mu_{O}^{\prime}=91.25 \mathrm{yr}^{-1}$. Mortality for both types of plankton, $M=73 \mathrm{yr}^{-1}$.

$\mathrm{N}_{2}$-fixers are given a lower maximum growth rate on $P$ because of the energy demands of $\mathrm{N}_{2}$-fixation. Thus if $P$ is limiting they are out-competed, but this removes a source of $N$ to the system, and $N$ drops until the system settles into an $\mathrm{N}$-limited state. In that state, there is negative feedback on changes in $N$ - should $N$ increase, $\mathrm{N}_{2}$-fixers will tend to be out-competed by other plankton, conversely, should $N$ drop, $\mathrm{N}_{2}$-fixers tend to make up a larger fraction of the population. 
The model schematic (Fig. 2) illustrates the key fluxes of both nutrients. $N$ and $P$ are removed from the surface boxes by biological uptake, but for both nutrients, $S R=95 \%$ of total primary productivity is regenerated in the surface layer. Atmospheric $\mathrm{N}_{2}$ exchanges with seawater where it is fixed directly into $\mathrm{N}_{2}$-fixers, and enters box $A$ as available $N$ via their mortality and remineralisation. $N$ is removed from the system by denitrification, with $D N=1.5 \%$ of total $\mathrm{N}$ uptake converted to $\mathrm{N}_{2}$ via denitrification, $75 \%$ of this in the surface layer. Mixing of water $\left(K=3.0 \mathrm{~m} \mathrm{yr}^{-1}\right)$ with the deep box provides a net input of nutrients to each surface box. $N$ also enters the surface boxes from rivers $\left(R N=6.0 \times 10^{-3} \mathrm{~mol} \mathrm{~N} \mathrm{~m}^{-2} \mathrm{yr}^{-1}\right)$ and atmospheric deposition $\left(A N=7.5 \times 10^{-3}\right.$ mol N m$\left.{ }^{-2} \mathrm{yr}^{-1}\right)$, whilst $P$ enters only from rivers $\left(R P=2.0 \times 10^{-4} \mathrm{~mol} \mathrm{P} \mathrm{m}^{-2} \mathrm{yr}^{-1}\right)$. All these fluxes determine the rate of change of nutrient concentrations in the surface ocean boxes, described by:

$$
\begin{aligned}
\frac{d P_{A}}{d t}= & -\mu_{N F}^{\prime} \times \frac{P_{A}}{P_{A}+P_{H}} \times \frac{N F_{A}}{R_{N F}} \\
& -\mu_{O}^{\prime} \times \min \left(\frac{P_{A}}{P_{A}+P_{H}}, \frac{N_{A}}{N_{A}+N_{H}}\right) \times \frac{O_{A}}{R_{O}} \\
& +M \times S R \times \frac{N F_{A}}{R_{N F}}+M \times S R \times \frac{O_{A}}{R_{O}} \\
& +\frac{K \times\left(P_{D}-P_{A}\right)}{S D}+\frac{R P}{S D} \\
\frac{d N_{A}}{d t}= & -\mu_{O}^{\prime} \times \min \left(\frac{P_{A}}{P_{A}+P_{H}}, \frac{N_{A}}{N_{A}+N_{H}}\right) \times O_{A} \\
& +M \times(S R-0.75 \times D N) \times N F_{A} \\
& +M \times(S R-0.75 \times D N) \times O_{A} \\
& +\frac{K \times\left(N_{D}-N_{A}\right)}{S D}+\frac{(R N+A N)}{S D} \\
\frac{d P_{B}}{d t}= & -\mu_{O}^{\prime} \times \min \left(\frac{P_{B}}{P_{B}+P_{H}}, \frac{N_{B}}{N_{B}+N_{H}}\right) \times \frac{O_{B}}{R_{O}} \\
& +M \times S R \times \frac{O_{B}}{R_{O}}+\frac{K \times\left(P_{D}-P_{B}\right)}{S D}+\frac{R P}{S D} \\
\frac{d N_{B}}{d t}= & -\mu_{O}^{\prime} \times \min \left(\frac{P_{B}}{P_{B}+P_{H}}, \frac{N_{B}}{N_{B}+N_{H}}\right) \times O_{B} \\
& +M \times(S R-0.75 \times D N) \times O \\
& +\frac{K \times\left(N_{D}-N_{B}\right)}{S D}+\frac{(R N+A N)}{S D}
\end{aligned}
$$

where $S D=500 \mathrm{~m}$ is the depth of the surface layer.

Nutrients enter the deep ocean via remineralisation with $D R=4.8 \%$ of total primary productivity regenerated in the deep layer (leaving $0.2 \%$ to leave the system via burial in sediments). Denitrification ( $25 \%$ of $D N$ ) removes some $N$ from the sinking flux. There is also a net removal of both nutrients from the deep box due to mixing with the surface boxes. These fluxes determine the rate of change of nutrient concentrations in the deep ocean, given by:

$$
\begin{aligned}
\frac{d P_{D}}{d t}= & M \times D R \times \frac{N F_{A}}{R_{N F}} \times \frac{f_{A} \times S D}{D D} \\
& +M \times D R \times \frac{O_{A}}{R_{O}} \times \frac{f_{A} \times S D}{D D} \\
& +M \times D R \times \frac{O_{B}}{R_{O}} \times \frac{f_{B} \times S D}{D D} \\
& -\frac{K \times\left(P_{D}-f_{A} P_{A}-f_{B} P_{B}\right)}{D D} \\
\frac{d N_{D}}{d t}= & M \times(D R-0.25 \times D N) \times N F_{A} \times \frac{f_{A} \times S D}{D D} \\
& +M \times(D R-0.25 D N) \times O_{A} \times \frac{f_{A} \times S D}{D D} \\
& +M \times(D R-0.25 D N) \times O_{B} \times \frac{f_{B} \times S D}{D D} \\
& -\frac{K \times\left(N_{D}-f_{A} N_{A}-f_{B} N_{B}\right)}{D D} \\
&
\end{aligned}
$$

where $D D=3230 \mathrm{~m}$ is the depth of the deep layer.

Denitrification and $\mathrm{N}$ burial remove a constant fraction of the $\mathrm{N}$ taken up in net primary production from the system, providing a linear negative feedback on changes in $N$. $\mathrm{P}$ burial provides an equivalent linear negative feedback on changes in $P$.

Setting $f_{A}=1$ and $R_{N F}=R_{O}=16\left(=R_{\mathrm{ORG}}\right)$ recovers the original TT model. These equations were solved numerically with a Fortran program and using Mathematica software.

\subsection{Application of the models}

We use the two models in a complementary fashion. In the LW model, the distinction between the N:P ratio of the phytoplankton and the $\mathrm{N}: \mathrm{P}$ threshold that triggers $\mathrm{N}_{2}$-fixation allows us to first independently examine their influences on deep ocean N:P. These ratios are then equated in the LW model for the remainder of the Results. This assumes that competitive dynamics set the $\mathrm{N}: \mathrm{P}$ threshold for $\mathrm{N}_{2}$-fixation, which is implicit in the TT model. Under this assumption, we use both models to examine the effect of changes in phytoplankton $\mathrm{N}: \mathrm{P}$ on deep ocean N:P. We use the extended TT model to further examine the relative impact of independently varying the $\mathrm{N}: \mathrm{P}$ ratios of $\mathrm{N}_{2}$-fixers and nonfixers, and the effect of restricting $\mathrm{N}_{2}$-fixers to a progressively smaller fraction of the surface ocean. Then we use the LW model to examine the effects of changes in $\mathrm{C}: \mathrm{P}$ and $\mathrm{C}: \mathrm{N}$ as well as $\mathrm{N}: \mathrm{P}$ ratios of the phytoplankton, and the effect of changes in weathering. In all cases we concentrate on the steady state solutions of the models, rather than their transient responses. In response to changes in phytoplankton stoichiometry and/or the $\mathrm{N}: \mathrm{P}$ threshold that triggers $\mathrm{N}_{2}$ fixation, steady state is achieved over $10^{4}-10^{5} \mathrm{yr}$, whereas in response to changes in weathering it takes $10^{6}-10^{7} \mathrm{yr}$.

\section{Results}

\subsection{What controls deep ocean N:P?}

From the analytical solution of the LW model for steady state (Sect. 2.1) (valid for normalised weathering forcing $0 \leq W \leq 1.163$ ), we find the following solutions for the ratio of available nitrogen $\left(\mathrm{NO}_{3}\right)$ and phosphorus $\left(\mathrm{PO}_{4}\right)$ in the deep ocean. When $\mathrm{NO}_{3}$ is limiting:

$$
\frac{\mathrm{NO}_{3}}{\mathrm{PO}_{4}}=\left(\frac{1}{r_{\mathrm{N}: \mathrm{P}, \mathrm{Fix}}}+\frac{r_{\mathrm{C}: \mathrm{N}} k_{P}}{C_{0} W^{\frac{1}{2}}}(4.025-3.025 W)\right)^{-1}
$$

When $\mathrm{PO}_{4}$ is limiting:

$$
\frac{\mathrm{NO}_{3}}{\mathrm{PO}_{4}}=r_{\mathrm{N}: \mathrm{P}, \mathrm{Fix}}\left(1-\frac{r_{\mathrm{C}: \mathrm{P}} k_{P}}{C_{0} W^{\frac{1}{2}}}(4.025-3.025 W)\right)
$$

The condition for $\mathrm{NO}_{3}$ to be limiting is:

$$
\frac{1}{r_{\mathrm{C}: \mathrm{P}}}-\frac{1}{r_{\mathrm{C}: \mathrm{N}} r_{\mathrm{N}: \mathrm{P}, \mathrm{Fix}}} \leq \frac{k_{P}}{C_{0} W^{\frac{1}{2}}}(4.025-3.025 W)
$$




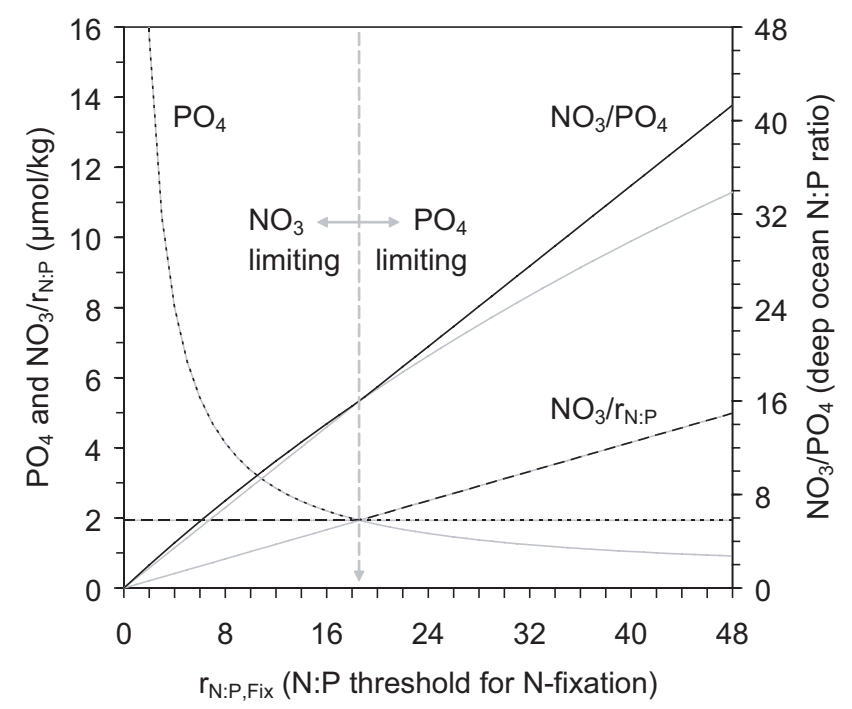

Fig. 3. Analytic solutions for the dependence of steady state $\mathrm{PO}_{4}$ (dotted line), $\mathrm{NO}_{3} / r_{\mathrm{N}: \mathrm{P}}$ (dashed line), and deep ocean $\mathrm{N}: \mathrm{P}$ ratio (solid line) on the $\mathrm{N}: \mathrm{P}$ threshold for $\mathrm{N}_{2}$-fixation $\left(r_{\mathrm{N}}\right.$ :P,Fix $)$, in the LW model. Here the N:P Redfield ratio (i.e. the composition of all phytoplankton) is fixed at $r_{\mathrm{N}: \mathrm{P}}=16$. We plot $\mathrm{NO}_{3} / r_{\mathrm{N}: \mathrm{P}}$ rather than $\mathrm{NO}_{3}$ to visually indicate whether $\mathrm{PO}_{4}$ or $\mathrm{NO}_{3}$ is limiting. The pale grey solid lines show the solutions for both $\mathrm{NO}_{3}$ limiting and $\mathrm{PO}_{4}$ limiting conditions throughout. However, for a given value of $r_{\mathrm{N}: \mathrm{P}, \text { Fix }}$, only one set of solutions is valid and self-consistent. The space divides into two regimes, one where $\mathrm{NO}_{3}$ is limiting and the other where $\mathrm{PO}_{4}$ is limiting (when $r_{\mathrm{N} \text { :P,Fix }} \geq 18.6$ ).

For the default parameter values, $\mathrm{NO}_{3}$ is limiting. However, if the $\mathrm{N}: \mathrm{P}$ threshold that triggers $\mathrm{N}_{2}$-fixation $\left(r_{\mathrm{N}}\right.$ :P,Fix $)$ and the $\mathrm{N}$ :P Redfield ratio $\left(r_{\mathrm{N}: \mathrm{P}}\right)$ can be decoupled, then $\mathrm{PO}_{4}$ limitation can be triggered by increasing $r_{\mathrm{N}: \mathrm{P}, \mathrm{Fix}}$, or by decreasing $r_{\mathrm{N}: \mathrm{P}}$ (by either decreasing $r_{\mathrm{C}: \mathrm{P}}$ or by increasing $r_{\mathrm{C}: \mathrm{N}}$ ).

Figures 3 and 4 show, for present day weathering $W=1$, the effects of independently varying $r_{\mathrm{N}: \mathrm{P}, \mathrm{Fix}}, r_{\mathrm{C}: \mathrm{P}}$, or $r_{\mathrm{C}: \mathrm{N}}$ on $\mathrm{NO}_{3} / r_{\mathrm{N}: \mathrm{P}}, \mathrm{PO}_{4}$, and the deep ocean $\mathrm{N}: \mathrm{P}$ ratio. With fixed $W=1$, atmospheric oxygen, new production, and ocean anoxia are constant at their initial values (from Eqs. 15-17).

Deep ocean N:P is primarily controlled by the N:P threshold that triggers $\mathrm{N}_{2}$-fixation, $r_{\mathrm{N}: \mathrm{P} \text {,Fix }}$ (Fig. 3). Considering Eqs. (33) and (34), $k_{P}=0.26875 \mu \mathrm{mol} \mathrm{kg}^{-1}$ is small, therefore deep ocean N:P is set modestly below $r_{\mathrm{N}: \mathrm{P}, \mathrm{Fix}}$, whether $\mathrm{N}$ or $\mathrm{P}$ is limiting. In mechanistic terms, denitrification in the water column and sediments, plus a small amount of organic nitrogen burial, continually remove $\mathrm{N}$ from the ocean, thus lowering deep ocean N:P and supporting a counterbalancing flux of $\mathrm{N}_{2}$-fixation. For the default parameter values shown, in the $\mathrm{N}$-limiting regime, deep ocean $\mathrm{N}: \mathrm{P}$ tends toward $r_{\mathrm{N} \text { :P,Fix }}$ as $r_{\mathrm{N}: \mathrm{P}, \text { Fix }}$ tends to zero. When $r_{\mathrm{N}: \mathrm{P}, \text { Fix }}$ is increased, this tends to transiently increase $\mathrm{N}_{2}$-fixation, $\mathrm{NO}_{3}$, new production, Org-P and Ca-P burial until steady state is restored with lower $\mathrm{PO}_{4}$, identical $\mathrm{NO}_{3}$ and consequently higher deep ocean N:P. When $r_{\mathrm{N}: \mathrm{P}, \mathrm{Fix}} \geq 18.6$, a switch to P- limitation occurs. Now as $r_{\mathrm{N}}$ P, Fix is increased further, increases in $\mathrm{N}_{2}$-fixation increase steady-state $\mathrm{NO}_{3}$ (because it is no longer limiting) without affecting $\mathrm{PO}_{4}$ (which remains constant). Thus deep ocean $\mathrm{N}: \mathrm{P}=0.86 r_{\mathrm{N}: \mathrm{P}, \text { Fix }}$ increases linearly.

When the $\mathrm{N}: \mathrm{P}$ threshold triggering $\mathrm{N}_{2}$-fixation is fixed at $r_{\mathrm{N}: \mathrm{P} \text {,Fix }}=16$, varying the N:P Redfield ratio - by varying either C:P or C:N - has little effect on the deep ocean N:P ratio (Fig. 4), although the concentrations of $\mathrm{NO}_{3}$ and $\mathrm{PO}_{4}$ can be substantially altered.

When varying $r_{\mathrm{C}: \mathrm{P}}$ with fixed $r_{\mathrm{C}: \mathrm{N}}=7.3125$ (Fig. 4a), if the system is in the $\mathrm{N}$-limiting regime, deep ocean $\mathrm{N}: \mathrm{P}$ ratio remains constant at $14.04\left(r_{\mathrm{C}: \mathrm{P}}\right.$ does not appear in Eq. 33). Indeed the concentrations of both nutrients are constant (Eqs. 20-21) because changes in C:P do not alter any of the controlling fluxes when $\mathrm{N}$ is limiting and $\mathrm{C}: \mathrm{N}$ is constant. If $r_{\mathrm{C}: \mathrm{P}} \leq 102.7$ (corresponding to $r_{\mathrm{N}: \mathrm{P}} \leq 14.04$ ), a switch to P-limitation occurs. Further decreases in $r_{\mathrm{C}: \mathrm{P}}$ transiently reduce new production, Org-P burial, Ca-P burial, Org-N burial, anoxia and denitrification until steady state is restored with higher concentrations of both $\mathrm{NO}_{3}$ and $\mathrm{PO}_{4}$. Deep ocean N:P increases linearly with decreasing $r_{\mathrm{C}: \mathrm{P}}$, tending toward $r_{\mathrm{N}: \mathrm{P}, \mathrm{Fix}}=16$ as $r_{\mathrm{C}: \mathrm{P}}$ tends toward zero.

When varying $r_{\mathrm{C}: \mathrm{N}}$ with fixed $r_{\mathrm{C}: \mathrm{P}}=117$ (Fig. $4 \mathrm{~b}$ ), in the $\mathrm{N}$-limiting regime, deep ocean $\mathrm{N}: \mathrm{P}$ ratio shows a weak sensitivity to $r_{\mathrm{C}: \mathrm{N}}$ (Eq. 33). As $r_{\mathrm{C}: \mathrm{N}}$ is decreased (corresponding to increasing $r_{\mathrm{N}: \mathrm{P}}$ ), deep ocean $\mathrm{N}: \mathrm{P}$ tends toward $r_{\mathrm{N}: \mathrm{P} \text {, Fix }}$. As $r_{\mathrm{C}: \mathrm{N}}$ is increased, transient increases in new production, Org-P burial, Ca-P burial, Org-N burial, anoxia and denitrification give rise to a new steady state with lower concentrations of both $\mathrm{NO}_{3}$ and $\mathrm{PO}_{4}$. If $r_{\mathrm{C}: \mathrm{N}} \geq 8.49$ (corresponding to $\left.r_{\mathrm{N}: \mathrm{P}} \leq 13.77\right)$, a switch to P-limitation occurs. In this regime, $r_{\mathrm{C}: \mathrm{N}}$ has no effect on either $\mathrm{NO}_{3}$ or $\mathrm{PO}_{4}$ (Eqs. 22-23) and deep ocean $\mathrm{N}: \mathrm{P}$ is constant at 13.77 .

Thus, a systematic change in phytoplankton C:N:P stoichiometry can alter the concentrations of $\mathrm{NO}_{3}$ and $\mathrm{PO}_{4}$ in the deep ocean but cannot greatly alter their ratio, unless it also alters the N:P threshold for $\mathrm{N}_{2}$-fixation. This is a useful insight from the model, particularly if in reality $r_{\mathrm{N}: \mathrm{P}}$ and $r_{\mathrm{N}: \mathrm{P} \text {,Fix }}$ can be decoupled. However, it may be of limited applicability to the real ocean, because (as we will assume for the remainder of the Results section) changes in the N:P requirement of the phytoplankton are expected to alter the $\mathrm{N}: \mathrm{P}$ threshold for $\mathrm{N}_{2}$-fixation. In particular, it is implicit in Redfield's (1958) mechanism that the N:P level triggering $\mathrm{N}_{2}$-fixation cannot be decoupled from the N:P ratio of the phytoplankton because the latter sets the threshold below which $\mathrm{N}_{2}$-fixers are selected and $\mathrm{N}_{2}$-fixation occurs. This can be explained in terms of competitive dynamics (Schade et al., 2005): If the $\mathrm{N}: \mathrm{P}$ supply ratio in the water is below the $\mathrm{N}: \mathrm{P}$ requirement of non-fixers, then they will use up all the $\mathrm{N}$ and leave some $\mathrm{P}$ remaining. $\mathrm{N}_{2}$-fixers can utilise this $\mathrm{P}$ and in so doing add fixed $\mathrm{N}$ to the system. This will continue until the N:P supply ratio approaches the N:P requirement of the non-fixers, at which point the $\mathrm{N}_{2}$-fixers tend to 

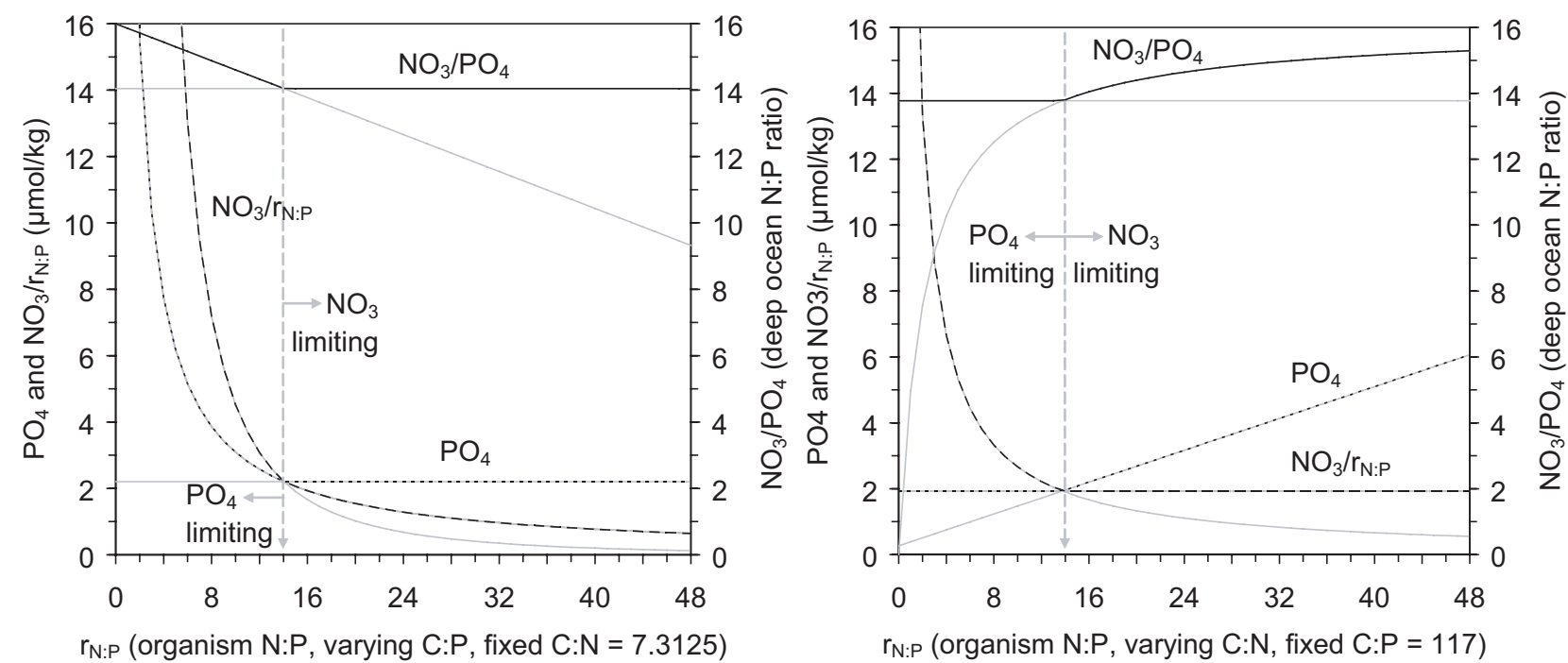

Fig. 4. Analytic solutions for the dependence of steady state $\mathrm{PO}_{4}$ (dotted line), $\mathrm{NO}_{3} / r_{\mathrm{N}: \mathrm{P}}$ (dashed line), and deep ocean $\mathrm{N}: \mathrm{P}$ ratio (solid line) on the N:P Redfield ratio $\left(r_{\mathrm{N}: \mathrm{P}}\right)$, when the N:P threshold for $\mathrm{N}_{2}$-fixation is fixed at $r_{\mathrm{N}: \mathrm{P} \text {,Fix }}=16$, in the LW model. (a) Fixing the C:N Redfield ratio at $r_{\mathrm{C}: \mathrm{N}}=117 / 16=7.3125$. Here in the $\mathrm{N}$-limiting regime, deep ocean $\mathrm{N}: \mathrm{P}=14.04$, and a switch to $\mathrm{PO}_{4}$ limitation occurs when $r_{\mathrm{N}: \mathrm{P}} \leq 14.04$. (b) Fixing the $\mathrm{C}: \mathrm{P}$ Redfield ratio at $r_{\mathrm{C}: \mathrm{P}}=117$. Here the switch to $\mathrm{PO}_{4}$ limitation occurs when $r_{\mathrm{N}: \mathrm{P}} \leq 13.77$, and this regime has deep ocean $\mathrm{N}: \mathrm{P}=13.77$. Other details are as in Fig. 3.

be out-competed because $\mathrm{N}_{2}$-fixation is an energy demanding process.

3.2 Assuming competitive dynamics set the N:P threshold for $\mathrm{N}_{2}$-fixation

In the LW model, if we assume that the average $\mathrm{N}: \mathrm{P}$ ratio of the phytoplankton is the $\mathrm{N}: \mathrm{P}$ ratio that triggers $\mathrm{N}_{2}$-fixation (i.e. $r_{\mathrm{N}: \mathrm{P}, \mathrm{Fix}}=r_{\mathrm{C}: \mathrm{P}} / r_{\mathrm{C}: \mathrm{N}}=r_{N: P}$ ), then $\mathrm{NO}_{3}=C_{0} / r_{\mathrm{C}: \mathrm{N}}$ is always limiting, $\mathrm{PO}_{4}=\left(C_{0} / r_{\mathrm{C}: \mathrm{P}}\right)+k_{P}$ and deep ocean $\mathrm{N}: \mathrm{P}$ :

$$
\frac{\mathrm{NO}_{3}}{\mathrm{PO}_{4}}=r_{\mathrm{N}: \mathrm{P}}\left(\frac{1}{1+r_{\mathrm{C}: \mathrm{P}} k_{P} / C_{0}}\right)
$$

In the original TT model this assumption is implicit because competition between $\mathrm{N}_{2}$-fixers and non-fixers is made explicit. They have identical N:P ratios $\left(r_{\mathrm{N}: \mathrm{P}}=R_{O}=R_{N F}\right.$, which was $R_{\mathrm{ORG}}$ in TT's notation). $\mathrm{N}_{2}$-fixers are given a lower maximum growth rate on $\mathrm{P}$ because of the energy demands of $\mathrm{N}_{2}$-fixation. For the default parameter settings including a fixed weathering flux of $\mathrm{P}$ to the ocean, deep ocean $\mathrm{PO}_{4}=1.75 \mu \mathrm{mol} \mathrm{kg}-1$ and the deep ocean $\mathrm{N}: \mathrm{P}$ ratio:

$\frac{\mathrm{NO}_{3}}{\mathrm{PO}_{4}}=\frac{\left(r_{\mathrm{N}: \mathrm{P}} \times 1.475\right)+2}{1.75}$

Hence in both models, if it is assumed that the N:P ratio of the phytoplankton $\left(r_{\mathrm{N}: \mathrm{P}}\right)$ determines the N:P threshold that triggers $\mathrm{N}_{2}$-fixation $\left(r_{\mathrm{N}: \mathrm{P}, \mathrm{Fix}}=r_{N: P}\right.$ in $\left.\mathrm{LW}\right)$, then the deep ocean N:P ratio will track changes in $r_{\mathrm{N}: \mathrm{P}}$, dropping further below it the more $r_{\mathrm{N}: \mathrm{P}}$ is increased (Fig. 5). This

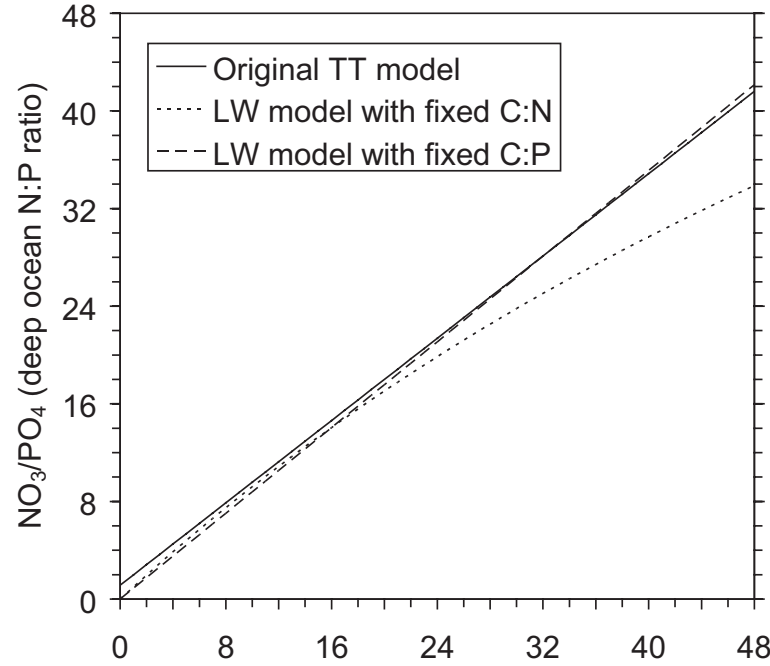

$r_{N: P}\left(\right.$ organism N:P) $=r_{N: P, F i x}(N: P$ threshold for $N$-fixation $)$

Fig. 5. Analytic solutions for the dependence of the steady state deep ocean N:P ratio on the N:P Redfield ratio of the phytoplankton, when assuming that it determines the $\mathrm{N}: \mathrm{P}$ threshold that triggers $\mathrm{N}_{2}$-fixation $\left(r_{\mathrm{N}: \mathrm{P}}=r_{\mathrm{N}}\right.$ P,Fix in the LW model). This assumption is implicit in the TT model for the default parameter settings. Results for the original TT model (solid line), and the LW model when assuming either fixed C:N Redfield ratio $\left(r_{\mathrm{C}: \mathrm{N}}=117 / 16=7.3125\right.$, dotted line) or fixed C:P Redfield ratio $\left(r_{\mathrm{C}: \mathrm{P}}=117\right.$, dashed line). 


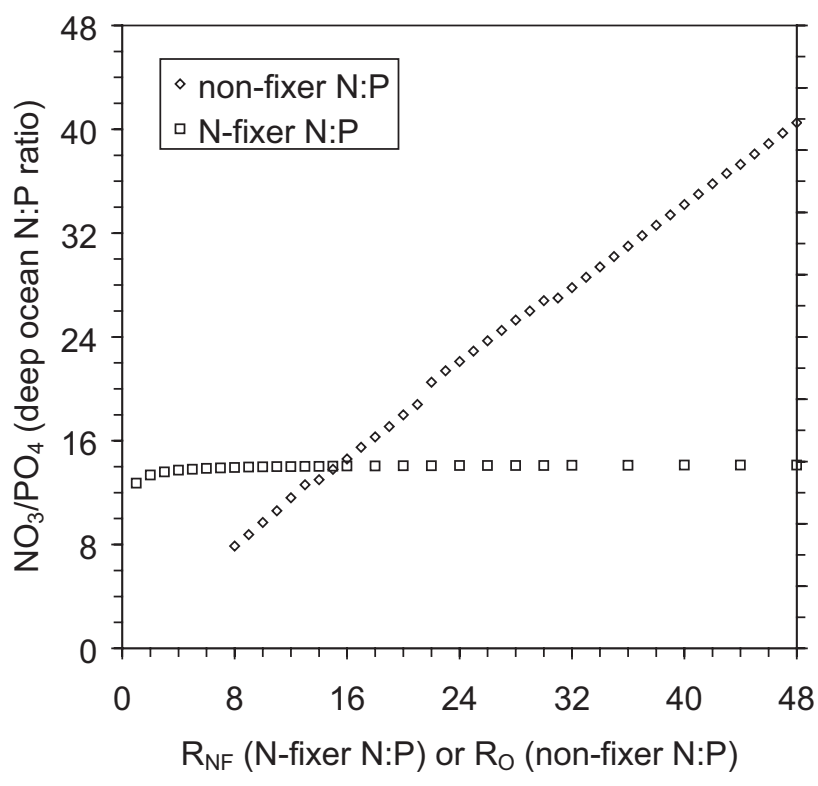

Fig. 6. Numerical solutions for the dependence of the deep ocean $\mathrm{N}: \mathrm{P}$ ratio on the $\mathrm{N}: \mathrm{P}$ Redfield ratio of either $\mathrm{N}_{2}$-fixing organisms, $R_{N F}$ (squares) or other non-fixers, $R_{O}$ (diamonds), in the extended TT model. When varying one Redfield ratio the other is held constant at 16. A stable steady state could not be found for $R_{O}=7$ or less.

is consistent with the direct dependence of deep ocean $\mathrm{N}: \mathrm{P}$ on decoupled changes in the N:P threshold that triggers $\mathrm{N}_{2}$ fixation (Fig. 3) and may be contrasted with the insensitivity of deep ocean N:P to de-coupled changes in phytoplankton $\mathrm{N}: \mathrm{P}$ (Fig. 4). In the TT model, fixing the weathering flux of $\mathrm{P}$ to the ocean gives a constant deep ocean $\mathrm{PO}_{4}$ at steady state, which is equivalent to fixing the C:P Redfield ratio $\left(r_{\mathrm{C}: \mathrm{P}}\right)$ in the LW model. In both cases (Fig. 5), deep ocean N:P linearly tracks the phytoplankton $\mathrm{N}: \mathrm{P}$ ratio entirely through changes in $\mathrm{NO}_{3}$. The only difference between the models is in the default gradient ( 0.84 in TT, 0.88 in LW) and offset (1.14 in TT, 0 in LW) of the relationship.

If the C:N Redfield ratio is fixed in the LW model, then $\mathrm{NO}_{3}$ is fixed and deep ocean $\mathrm{N}: \mathrm{P}$ tracks phytoplankton $\mathrm{N}: \mathrm{P}$ entirely through changes in $\mathrm{PO}_{4}$. In this case, it is instructive to re-write Eq. (36) in the form:

$$
\frac{\mathrm{NO}_{3}}{\mathrm{PO}_{4}}=\frac{r_{\mathrm{N}: \mathrm{P}}}{1+r_{\mathrm{N}: \mathrm{P}} r_{\mathrm{C}: \mathrm{N}} k_{P} / C_{0}}
$$

Now, the larger the N:P ratio of the phytoplankton, the further the deep ocean N:P ratio drops below it (Fig. 5). However, as $r_{\mathrm{C}: \mathrm{N}} k_{P} / C_{0}$ is small, the offset is modest.

\subsection{Relative effects of $\mathrm{N}_{2}$-fixer and non-fixer N:P}

Our extension of the TT model to include different N:P ratios for $\mathrm{N}_{2}$-fixers and non-fixers, allows us to examine their relative effects on the deep ocean $\mathrm{N}: \mathrm{P}$ ratio. $\mathrm{N}_{2}$-fixers often

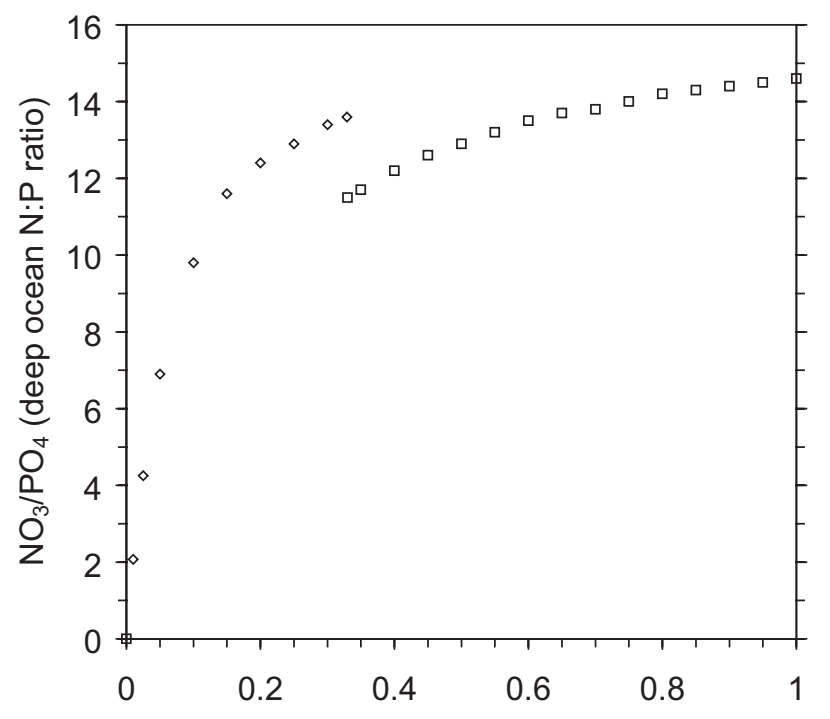

Fraction of surface ocean $\left(f_{\mathrm{A}}\right)$ occupied by $\mathrm{N}$-fixers

Fig. 7. Dependence of the deep ocean N:P ratio on the fraction of the surface ocean occupied by $\mathrm{N}_{2}$-fixers $\left(f_{A}\right)$ in the extended TT model, assuming an N:P Redfield ratio of 16 for both $\mathrm{N}_{2}$-fixers and other phytoplankton. Square symbols indicate a stable solution, diamond symbols a limit cycle (oscillating solution). The oscillations are small, with a maximum amplitude of $\sim 0.75 \%$ (e.g. $13.3-13.5$ for $f_{A}=0.3$ ), and the diamonds are plotted at the mid point of the oscillations. The transition from a stable steady state to a limit cycle occurs in the range $f_{A}=0.329-0.330$.

have a higher $\mathrm{N}: \mathrm{P}$ ratio than non-fixers (Klausmeier et al., 2004 ) with reported $\mathrm{N}: \mathrm{P}$ values for $\mathrm{N}_{2}$-fixing Trichodesmium colonies ranging from 18.3 (Sañudo-Wilhelmy et al., 2001) to 125 (Karl et al., 1992). However, this should have little effect on the $\mathrm{N}: \mathrm{P}$ of deep water, because the density of $\mathrm{N}_{2}$ fixers is regulated by the $\mathrm{N}: \mathrm{P}$ requirements of the non-fixers. Model results (Fig. 6) confirm this; for example, steady-state deep water $\mathrm{N}: \mathrm{P}$ ratio is 14.6 when $\mathrm{N}_{2}$-fixers have an $\mathrm{N}: \mathrm{P}$ ratio of 16 and 14.7 when $\mathrm{N}_{2}$-fixers have an N:P ratio of 125 . In contrast, deep ocean $\mathrm{N}: \mathrm{P}$ ratio varies linearly with the $\mathrm{N}: \mathrm{P}$ ratio of non-fixers (Fig. 6). Thus, contrary to Redfield (1958) (as quoted in Sect. 1), it is the N:P ratio of non-fixers (rather than $\mathrm{N}_{2}$-fixers) that sets the $\mathrm{N}: \mathrm{P}$ threshold for $\mathrm{N}_{2}$-fixation, which consequently determines the deep ocean $\mathrm{N}: \mathrm{P}$ ratio.

3.4 What if $\mathrm{N}_{2}$-fixation is restricted to a fraction of the surface ocean?

If $\mathrm{N}_{2}$-fixation is restricted to a progressively smaller fraction $\left(f_{A}\right)$ of the surface ocean, we find that deep ocean $\mathrm{N}: \mathrm{P}$ is remarkably well regulated (Fig. 7). As $f_{A}$ is reduced from 1 to 0.33 , steady state deep ocean $\mathrm{N}: \mathrm{P}$ declines from 14.6 to 11.5; for example, when only $50 \%$ of the ocean is available to $\mathrm{N}_{2}$-fixers, deep $\mathrm{N}: \mathrm{P}$ is 12.9 . As $f_{A}$ is reduced below 0.33 , the system undergoes a Hopf bifurcation to an oscillating 
Table 2. Limits on ocean composition predicted from theoretical limits on the N:P stoichiometry of phytoplankton (Klausmeier et al., 2004) using the TT and LW models, and assuming in the latter that phytoplankton N:P is the N:P threshold that triggers $\mathrm{N}_{2}$-fixation.

\begin{tabular}{lcccc}
\hline \multirow{2}{*}{ Limit } & Phytoplankton N:P & \multicolumn{3}{c}{ Predicted N:P of deep ocean } \\
\cline { 3 - 5 } & & TT & LW with & LW with \\
& & & $r_{\mathrm{C}: \mathrm{P}=117}$ & $r_{\mathrm{C}: \mathrm{N}}=7.3$ \\
\hline Control & 16 & 14.6 & 14.0 & 14.0 \\
Exponential growth & 8.2 & 8.1 & 7.2 & 7.7 \\
Light limitation & 35.8 & 31.3 & 31.4 & 27.3 \\
N-limitation & 37.4 & 32.7 & 32.8 & 28.2 \\
P-limitation & 45.0 & 39.1 & 39.5 & 32.3 \\
\hline
\end{tabular}

Table 3. Expected ocean composition if dominated by various phyla of phytoplankton. Predicted from the Redfield ratios found by (Quigg et al., 2003) and the adapted LW model, assuming the N:P Redfield ratio is the threshold below which $\mathrm{N}_{2}$-fixation occurs.

\begin{tabular}{lcccc}
\hline $\begin{array}{l}\text { Phylum/superfamily } \\
\text { (and age) }\end{array}$ & $\mathrm{C}: \mathrm{N}: \mathrm{P}$ ratio & $\begin{array}{c}\mathrm{NO}_{3} \\
\left(\mu \mathrm{mol} \mathrm{kg}^{-1}\right)\end{array}$ & $\begin{array}{c}\mathrm{PO}_{4} \\
\left(\mu \mathrm{mol} \mathrm{kg}^{-1}\right)\end{array}$ & $\mathrm{NO}_{3}: \mathrm{PO}_{4}$ \\
\hline $\begin{array}{l}\text { Prasinophyceae } \\
\text { (1200 Myr) }\end{array}$ & $200: 25: 1$ & 28 & 1.4 & 20 \\
$\begin{array}{l}\text { Chlorophyceae } \\
(1000 \text { Myr) }\end{array}$ & $200: 33: 1$ & 38 & 1.4 & 27 \\
$\begin{array}{l}\text { Dinophyceae } \\
\text { (440 Myr) }\end{array}$ & $140: 13: 1$ & 21 & 1.9 & 11 \\
$\begin{array}{l}\text { Prymnesiophyceae } \\
(210 \mathrm{Myr})\end{array}$ & $60: 9: 1$ & 32 & 4.0 & 8.0 \\
$\begin{array}{l}\text { Diatoms } \\
(<200 \mathrm{Myr})\end{array}$ & $70: 10: 1$ & 32 & 3.5 & 9.2 \\
\hline
\end{tabular}

solution, and deep N:P actually increases, oscillating in the range $13.5-13.7$ for $f_{A}=0.329$. As $f_{A}$ is reduced further, deep N:P declines in a non-linear fashion; for example, when only $25 \%$ of the ocean is available to $\mathrm{N}_{2}$-fixers, the deep $\mathrm{N}: \mathrm{P}$ oscillates in the range 12.8-13.0, whereas when $\mathrm{N}_{2}$-fixers are restricted to $15 \%$ of the surface ocean, deep N:P is still 11.511.7. As $f_{A}$ tends to zero, deep ocean $\mathrm{N}: \mathrm{P}$ also tends to zero, and in the absence of $\mathrm{N}_{2}$-fixers, the oscillations disappear.

Such homeostatic control over the deep ocean $\mathrm{N}: \mathrm{P}$ ratio is maintained in the model because $\mathrm{N}_{2}$-fixers reach higher densities when restricted to smaller fractions of the ocean's surface, compensating for their reduced distribution. Although the predicted values of deep N:P fall below those observed, this is sensitive to the choice of model parameters. If we assume that the N:P Redfield ratio of non-fixers $\left(R_{O}\right)$ is somewhat greater than 16 , this can compensate for restricting $\mathrm{N}_{2}$ fixers to a fraction of the ocean's surface, for example, with $f_{A}=0.5, R_{O}=18$ recovers a deep ocean $\mathrm{N}: \mathrm{P}=14.3$.

\subsection{What if the Redfield ratios change?}

Theoretical limits on the N:P requirements of phytoplankton of 8.2-45.0 have been estimated (Klausmeier et al., 2004).
Exponential growth favours greater allocation to P-rich assembly machinery and hence a lower N:P ratio. Competitive equilibrium favours greater allocation to $\mathrm{P}$-poor resourceacquisition machinery and hence a higher $\mathrm{N}: \mathrm{P}$ ratio. Whether light, $\mathrm{N}$ or $\mathrm{P}$ is limiting has a second-order effect, with $\mathrm{P}$ limitation favouring the least allocation to assembly and the highest N:P ratio. We take the estimated limits from Klausmeier et al. (2004) as plausible bounds on the composition of the phytoplankton.

Corresponding limits on deep ocean N:P can be derived for the TT model and for the LW model assuming $r_{\mathrm{N}: \mathrm{P}, \mathrm{Fix}}=r_{\mathrm{N}: \mathrm{P}}$ with either fixed $r_{\mathrm{C}: \mathrm{P}}$ or fixed $r_{\mathrm{C}: \mathrm{N}}$ (Table 2 and Fig. 5). All three model variants give similar results. Fixed $r_{\mathrm{C}: \mathrm{N}}$ in the LW model is the most defendable, because existing data indicate that phytoplankton $\mathrm{C}: \mathrm{N}$ is less variable than $\mathrm{N}: \mathrm{P}$ and C:P (Geider and La Roche, 2002; Quigg et al., 2003). This model variant suggests that deep ocean N:P has a maximum range of 7.7-32.3 (i.e. about a factor of 2 either side of deep ocean values in the modern ocean).

We can also use the LW model to consider the effect on ocean composition of systematic changes in the phytoplankton $\mathrm{C}: \mathrm{N}: \mathrm{P}$ over evolutionary time (Quigg et al., 2003), assuming that changes in phytoplankton N:P drove 


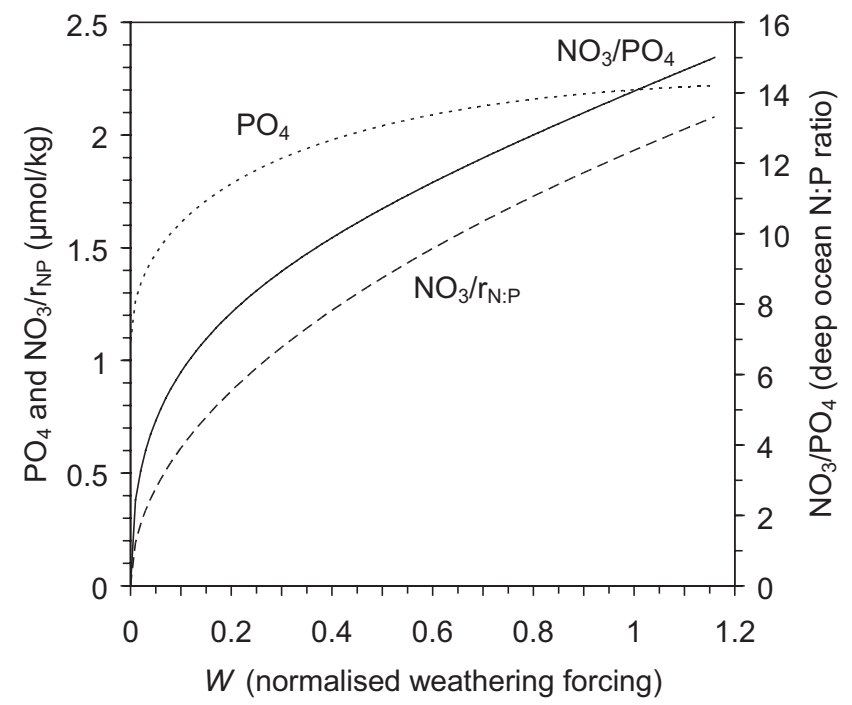

Fig. 8. Analytic solutions for the dependence of steady state $\mathrm{PO}_{4}$ (dotted line), $\mathrm{NO}_{3} / r_{\mathrm{N}: \mathrm{P}}$ (dashed line), and deep ocean $\mathrm{N}: \mathrm{P}$ ratio (solid line) on weathering forcing $(W)$ in the LW model. Note that steady state is only achieved for $W \leq 1.163$.

corresponding changes in the $\mathrm{N}: \mathrm{P}$ threshold triggering $\mathrm{N}_{2}$ fixation $\left(r_{\mathrm{N}: \mathrm{P}, \mathrm{Fix}}=r_{\mathrm{N}: \mathrm{P}}\right)$. Table 3 shows the ocean composition predicted (from Eq. 36) if it were dominated by each of a series of phyla/super-families of decreasing antiquity. This suggests that a general decrease in N:P ratios of marine phytoplankton over the past $\sim 1000 \mathrm{Myr}$ would have tended to decrease deep ocean $\mathrm{N}: \mathrm{P}$. This is predicted to have occurred via increasing ocean $\mathrm{PO}_{4}$, due to the general decrease in phytoplankton $\mathrm{C}: \mathrm{P}$, whereas the relative constancy of the phytoplankton $\mathrm{C}: \mathrm{N}$ ratio would not have forced $\mathrm{NO}_{3}$.

\subsection{What if phosphorus weathering changes?}

Thus far we have assumed weathering forcing $(W)$ is fixed, which has not been the case (Bergman et al., 2004; Lenton and Watson, 2004). The biological colonisation of the land surface has tended to accelerate weathering, in particular of phosphorus. This in turn has tended to increase atmospheric $\mathrm{O}_{2}$. Retaining the dependence on weathering forcing in the LW model but assuming $r_{\mathrm{N}: \mathrm{P}, \mathrm{Fix}}=r_{\mathrm{N}: \mathrm{P}}$ gives:

$$
\frac{\mathrm{NO}_{3}}{\mathrm{PO}_{4}}=r_{\mathrm{N}: \mathrm{P}}\left(1+\frac{r_{\mathrm{C}: \mathrm{P}} k_{P}}{C_{0} W^{\frac{1}{2}}}(4.025-3.025 W)\right)^{-1}
$$

A general increase in weathering forcing $(W)$ toward the present, due to biotic colonisation of the land surface would have tended to increase deep ocean N:P (Fig. 8), bringing it closer to the $\mathrm{N}: \mathrm{P}$ of the phytoplankton. The increase in deep ocean $\mathrm{N}: \mathrm{P}$ occurs through a proportionally greater increase in $\mathrm{NO}_{3}$ than $\mathrm{PO}_{4}$. The reason that $\mathrm{NO}_{3}$ drops more under decreased $W$ than $\mathrm{PO}_{4}$ is that $\mathrm{O}_{2}$ drops and anoxia increases
(Eqs. 16-17), and this both increases denitrification, lowering $\mathrm{NO}_{3}$, and encourages $\mathrm{Fe}-\mathrm{P}$ recycling from sediments, counteracting the decline in $\mathrm{P}$ input to the ocean.

\subsection{Combined effects}

We have predicted that over the past $\sim 1000 \mathrm{Myr}$, a decline in the N:P Redfield ratio and an increase in weathering forcing would have had counteracting effects on the deep ocean $\mathrm{N}: \mathrm{P}$ ratio, the former tending to decrease it, the latter to increase it. However, their effects are mediated by different nutrients. A declining N:P Redfield ratio with relatively constant $\mathrm{C}: \mathrm{N}$ tends primarily to increase $\mathrm{PO}_{4}$, whereas an increase in weathering tends primarily to increase $\mathrm{NO}_{3}$. The combined effect (given by Eq. 39) is rather complex, so let us consider an illustrative case: $\sim 1000 \mathrm{Myr}$ ago, we suggest $W=0.5$, and estimate $\mathrm{C}: \mathrm{N}: \mathrm{P}=200: 29: 1$ from averaging the values for Prasinophyceae and Chlorophyceae in Table 3 (Quigg et al., 2003). The predicted ocean composition is $\mathrm{NO}_{3}=23.2 \mu \mathrm{mol} \mathrm{kg}-1, \mathrm{PO}_{4}=1.47 \mu \mathrm{mol} \mathrm{kg}-1$, and deep ocean $\mathrm{N}: \mathrm{P}=15.7$. The lower $\mathrm{NO}_{3}$ relative to the present day is due entirely to the lower weathering rates and the lower $\mathrm{PO}_{4}$ is due primarily to the estimated higher C:P of the phytoplankton (compare the result with the top entries in Table 3).

\section{Discussion}

As Redfield recognised, phytoplankton C:N:P=106:16:1 simply represents an average of the present phytoplankton community, there is as yet no evidence that it is optimal, and $\mathrm{C}: \mathrm{N}: \mathrm{P}$ is now known to vary with growth conditions, among species, and (probably) over evolutionary time. We find that the $\mathrm{N}: \mathrm{P}$ ratio that triggers $\mathrm{N}_{2}$-fixation sets the $\mathrm{N}: \mathrm{P}$ ratio of the deep ocean (referring here to the average concentrations of $\mathrm{N}$ and $\mathrm{P}$, not the proportions in which they are remineralised). Hence deep ocean $\mathrm{N}: \mathrm{P}$ would be insensitive to changes in the N:P Redfield ratio of sinking material if there were no corresponding changes in the $\mathrm{N}: \mathrm{P}$ threshold that triggers $\mathrm{N}_{2}$ fixation. However, in reality all three N:P ratios are coupled: The N:P requirement of non-fixing phytoplankton determines the $\mathrm{N}: \mathrm{P}$ threshold for $\mathrm{N}_{2}$-fixation, and this in turn influences deep ocean N:P. Furthermore, $\mathrm{N}_{2}$-fixation can be limited by $\mathrm{Fe}$, temperature, light or other factors, such that $\mathrm{N}_{2}$-fixers are restricted to a modest fraction of the surface ocean, but they can still maintain deep ocean N:P relatively close to the N:P of non-fixing phytoplankton.

An additional mechanism not modelled herein is that phosphorite formation and consequent $\mathrm{P}$ removal from the ocean can be associated with fixed $\mathrm{N}$ removal due to denitrification (Piper and Codispoti, 1975; Schulz and Schulz, 2005). Qualitatively this acts in the right direction to further stabilise the deep ocean N:P ratio, although its effect will clearly depend on the (as yet unknown) proportions in which $\mathrm{N}$ and $\mathrm{P}$ are 
removed. However, it may not be quantitatively important because phosphorite formation in upwelling zones is a small part of the global sink for $\mathrm{P}$, and the associated denitrification is probably only a small part of the global sink for $\mathrm{N}$.

Our conclusions regarding deep ocean N:P are robust to uncertainties in the nutrient uptake parameters $\mathrm{P}_{\mathrm{H}}$ and $\mathrm{P}_{\mathrm{N}}$ (Cullen, 1999). Our simple approach of restricting $\mathrm{N}_{2}$-fixers to a decreasing fraction of the surface ocean may be reasonable for both temperature and light controls which vary inversely with latitude. However, it is not necessarily a good model for Fe-limitation and it would be interesting instead to limit the total biomass of $\mathrm{N}_{2}$-fixers, or to include an $\mathrm{Fe}$ cycle in the model. Our results with the extended TT model may also be sensitive to the formulation of competitive dynamics, in particular, allowing the competitive disadvantage for $\mathrm{N}_{2}$ fixers to be set by a lower maximum growth rate on P. In the real ocean, competition between $\mathrm{N}_{2}$-fixers and non-fixers occurs under low nutrient conditions, for which the optimal N:P ratio may be very high (Klausmeier et al., 2004). Under such conditions, $\mathrm{N}_{2}$-fixers, with an essentially unlimited $\mathrm{N}$ supply, may be able to synthesize more nutrient acquisition proteins and hence gain a competitive advantage (C. M. Moore, personal communication).

The models we use assume a tight coupling between the supply and assimilation of $\mathrm{N}$ and $\mathrm{P}$, which is not observed on annual timescales in some areas of the world ocean, notably High Nutrient Low Chlorophyll (HNLC) regions. However, if iron and/or light are the alternative limiting factors of primary productivity in such regions (e.g. the Southern Ocean) then they are unlikely to support $\mathrm{N}_{2}$-fixers anyway, and the model experiment is like the ones we show where $\mathrm{N}_{2}$-fixers are restricted to a fraction of the surface ocean.

We have restricted our analysis to times when the deep ocean was well oxygenated. In the anoxic world of the Archean, prior to $\sim 2400 \mathrm{Ma}$, iron would have been more abundant, removing one limiting factor on $\mathrm{N}_{2}$-fixation, and $\mathrm{N}$ would have been in the form of ammonium (Falkowski, 1997). With the rise of atmospheric $\mathrm{O}_{2}$ in the Great Oxidation Event $\sim 2400 \mathrm{Ma}$, nitrification and subsequent denitrification would have removed fixed $\mathrm{N}$ from the ocean, and a period with very low deep ocean $\mathrm{N}: \mathrm{P}$ has been predicted (Fennel et al., 2005). Once the ocean became fully oxygenated, nitrate would have built up and deep ocean N:P is predicted to have risen to values consistent with the present study (Fennel et al., 2005). However, the deep ocean may have remained anoxic and become sulphidic for much of the Proterozoic (Canfield, 1998). Under these conditions, trace metals including $\mathrm{Fe}$ and Mo would have been scarcer than they were in the Archean, potentially limiting both $\mathrm{N}_{2}$ fixation and denitrification (Anbar and Knoll, 2002). The full oxygenation of the deep ocean may not have occurred until a second significant rise in atmospheric $\mathrm{O}_{2}$ during the Neoproterozoic (Canfield, 1998; Lenton and Watson, 2004).

\subsection{Changes in deep ocean N:P since the Neoproterozoic}

The weathering flux of phosphorus to the ocean is thought to have increased with the biological colonisation of the land surface over the past $1000 \mathrm{Myr}$ (Lenton and Watson, 2004). Although this would have had some effect on ocean $\mathrm{PO}_{4}$, its dominant effect is predicted to have been an increase in ocean $\mathrm{NO}_{3}$, caused by increasing atmospheric $\mathrm{O}_{2}$ and consequently suppressing denitrification. Thus, a reduction in phosphorus weathering alone $\sim 1000$ Ma would have tended to reduce the deep ocean N:P ratio (Fig. 8).

Our model of the effects of changes in weathering is quite simplistic. The scavenging of $\mathrm{P}$ by iron oxides in an oxygenated ocean may be more effective than modelled. Also, the organic $\mathrm{C} / \mathrm{P}$ burial ratio may increase with anoxia (Van Cappellen and Ingall, 1996; Lenton and Watson, 2000). Both processes provide negative feedback on changes in atmospheric $\mathrm{O}_{2}$. Including the latter process in the LW model tends to maintain higher $\mathrm{O}_{2}$ and lower $\mathrm{PO}_{4}$ under reductions in weathering, but does not alter the $\mathrm{NO}_{3}$ prediction (Lenton and Watson, 2000). Consequently, the deep ocean N:P ratio tends to drop less under a reduction in weathering, but it still drops.

In contrast, members of phytoplankton groups that were present $\sim 1000$ Ma have higher N:P and C:P than today's average Redfield ratios (Quigg et al., 2003). Hence they do not have the composition expected if they had simply adapted to the ocean conditions predicted for the time they evolved. Instead, they are predicted to have altered those conditions: The higher N:P and C:P Redfield ratios $\sim 1000 \mathrm{Ma}$ would have tended to decrease $\mathrm{PO}_{4}$ and hence increase the deep ocean N:P ratio (Table 3).

Thus estimated changes in weathering and in phytoplankton composition over the past $\sim 1000 \mathrm{Myr}$ are predicted to have had counteracting effects on the deep ocean N:P ratio. These effects could fortuitously have cancelled at times, thus maintaining a similar deep ocean $\mathrm{N}: \mathrm{P}$ ratio to today (Sect. 3.7), but perfect or sustained cancelation are inherently improbable.

Our inferences here are necessarily speculative, because of a shortage of direct proxies for $\mathrm{NO}_{3}, \mathrm{PO}_{4}$ and hence the deep ocean N:P ratio. The lower $\mathrm{PO}_{4}$ predicted $\sim 1000 \mathrm{Ma}$ is consistent with much lower $\mathrm{PO}_{4}$ in the early Proterozoic $1900 \mathrm{Ma}$, followed by a rise in $\mathrm{PO}_{4}$ due to less removal on iron oxides (Bjerrum and Canfield, 2002). In response to the proposed increase in weathering over the past $1000 \mathrm{Myr}$, the LW model predicts proportional increases in total $\mathrm{P}$ and organic $\mathrm{C}$ burial. The $\mathrm{P}$ burial record only extends as far back as the oldest ocean floor $(\approx 160 \mathrm{Myr})$. However, changes in the $\delta^{13} \mathrm{C}$ records of carbonates and organic carbon during the Neoproterozoic have been used to infer an increase in the fraction of total carbon burial that occurs in organic form (Lenton and Watson, 2004). During the Phanerozoic, from the Devonian onwards, there is a further inferred increase in organic $\mathrm{C}$ burial and atmospheric $\mathrm{O}_{2}$, also supported by a 
predominance of rock types that are rich in organic carbon, and associated with rooted vascular plants colonizing the land surface (Lenton, 2001). There is clearly scope for further work testing the predictions of our hypothesis against the paleo record, potentially using the COPSE model (Bergman et al., 2004), which embeds the LW model.

Since the Neoproterozoic, there have been a few intervals, termed Oceanic Anoxic Events (OAEs), in which widespread anoxia returned to the deep ocean. During OAEs, denitrification and anammox would be greatly increased, tending to lower $\mathrm{NO}_{3}$ and the deep ocean $\mathrm{N}: \mathrm{P}$ ratio, and provoke a counter-balancing flux of $\mathrm{N}_{2}$-fixation (Kuypers et al., 2004). The LW model has been adapted to study OAEs (Handoh and Lenton, 2003) and the predicted decline in the deep ocean N:P ratio during them is modest $(\approx 20 \%)$, with the OAEs characterised by high levels of both $\mathrm{PO}_{4}$ and $\mathrm{NO}_{3}$ maintaining high productivity and hence anoxia. However, other causal scenarios for the OAEs are popular, particularly reduced ocean ventilation, and may have different consequences for deep ocean N:P. Also, a different model (without a full $\mathrm{O}_{2}$ cycle) finds a dramatic decrease of the deep ocean $\mathrm{N}: \mathrm{P}$ ratio with the onset of widespread anoxia (Wallmann, 2003). Hence our conclusions may not apply to OAEs.

\subsection{Co-evolution?}

We have extended Redfield's (1958) argument for the present ocean by adding an evolutionary time dimension, suggesting that over the last $\sim 1000 \mathrm{Myr}$, the composition of the marine environment has been altered by evolutionary changes in the composition of marine organisms, and by the biological colonisation of the land surface. This (and the modelling herein) describes a one-way interaction; biotic factors altering abiotic factors. However, phytoplankton composition may also adapt (within limits) to the composition of the ocean, which introduces the reverse interaction; abiotic factors shaping biotic factors. We have not modelled this here, but we acknowledge that it could qualitatively alter the results. Closing the loop between changes in biotic and abiotic factors would allow them to "co-evolve". One suggestion is that the predicted increase in $\mathrm{NO}_{3}$ and $\mathrm{PO}_{4}$ would result in more production being carried out under higher nutrient regimes, and therefore select for phytoplankton with lower $\mathrm{N}: \mathrm{P}$ ratios (C. M. Moore, personal communication). This provides a potential mechanism for "closing the loop" and explaining the lower N:P ratio within more recently evolved phyla. To examine such co-evolution we suggest that a model of competing populations with differing stoichiometry could be nested within a model of ocean composition subject to external drivers. The populations themselves could exhibit phenotypic plasticity in their stoichiometry as their resource allocation varies in response to prevailing conditions (Klausmeier et al., 2004). This is a topic for future work.

\section{Conclusion}

Despite potential changes in phytoplankton stoichiometry, weathering supply of phosphorus to the ocean, and widespread $\mathrm{Fe}$, temperature and/or light limitation of $\mathrm{N}_{2}$ fixation, we find that Redfield's mechanism can still regulate deep ocean N:P somewhat below the proportions that trigger $\mathrm{N}_{2}$-fixation in those areas of the ocean where $\mathrm{N}_{2}$-fixers are $\mathrm{P}$-limited and suppressed by $\mathrm{N}$ addition. Furthermore, deep ocean N:P is unlikely to have varied by more than a factor of two in either direction whilst the deep oceans have been well oxygenated (i.e. since the Neoproterozoic, with the possible exception of Oceanic Anoxic Events). We extend Redfield's mechanism to suggest that within these bounds, the evolution of phytoplankton composition and the biological colonisation of the land surface could have driven long-term changes in ocean composition. Biotic stoichiometric controls on ocean composition could have operated much faster than phosphorus weathering controls, because they do not involve changes in atmospheric $\mathrm{O}_{2}$.

Acknowledgements. We thank J. Elser and D. Hessen for organizing the workshop that triggered this work. M. Johnson, V. Livina, C. M. Moore, S. Roudesli, N. Stephens, H. Williams, three anonymous referees and the editor $\mathrm{C}$. Heinze all provided comments that helped improve the paper. T. M. Lenton thanks the European Geosciences Union for an Outstanding Young Scientist Award 2006 and the resulting invitation to contribute this paper. TML's work is supported by the Leverhulme Trust through a Philip Leverhulme Prize. This paper is also an output of the NERC "Quaternary QUEST" project (NE/D001706/1).

Edited by: W. Kiessling

\section{References}

Anbar, A. D. and Knoll, A. H.: Proterozoic Ocean Chemistry and Evolution: A Bioinorganic Bridge?, Science, 297, 1137-1142, 2002.

Anderson, L. A. and Sarmiento, J. L.: Redfield ratios of remineralization determined by nutrient data analysis, Global Biogeochem. Cy., 8, 65-80, 1994.

Arrigo, K. R.: Marine microorganisms and global nutrient cycles, Nature, 437, 349-355, 2005.

Bergman, N. M., Lenton, T. M., and Watson, A. J.: COPSE: a new model of biogeochemical cycling over Phanerozoic time, Am. J. Sci., 304, 397-437, 2004.

Berman-Frank, I., Cullen, J. T., Shaked, Y., Sherrell, R. M., and Falkowski, P. G.: Iron availability, cellular iron quotas, and nitrogen fixation in Trichodesmium, Limnol. Oceanogr., 46, 1249 1260, 2001.

Bjerrum, C. J. and Canfield, D. E.: Ocean productivity before about 1.9 Gyr ago limited by phosphorus adsorption onto iron oxides, Nature, 417, 159-162, 2002.

Breitbarth, E., Oeschlies, A., and LaRoche, J.: Physiological constraints on the global distribution of Trichodesmium - effect of temperature on diazotrophy, Biogeosciences, 4, 53-61, 2007, http://www.biogeosciences.net/4/53/2007/. 
Broecker, W. S. and Peng, T.-H.: Tracers in the Sea, Eldigio Press, New York, 1982.

Canfield, D. E.: A new model for Proterozoic ocean chemistry, Nature, 396, 450-453, 1998.

Codispoti, L. A.: Is the ocean losing nitrate?, Nature, 376, 724, 1995.

Cullen, J. J.: Iron, nitrogen and phosphorus in the ocean, Nature, 402, 372, 1999.

Dalsgaard, T., Canfield, D. E., Petersen, J., Thamdrup, B., and Acuna-Gonzalez, J.: $\mathrm{N}_{2}$ production by the anammox reaction in the anoxic water of Golfo Dulce, Costa Rica, Nature, 422, 606-608, 2003.

Deutsch, C., Sarmiento, J. L., Sigman, D. M., Gruber, N., and Dunne, J. P.: Spatial coupling of nitrogen inputs and losses in the ocean, Nature, 445, 163-167, 2007.

Falkowski, P. G.: Evolution of the nitrogen cycle and its influence on the biological sequestration of CO2 in the ocean, Nature, 387, 272-275, 1997.

Falkowski, P. G. and Davis, C. S.: Natural proportions, Nature, 431, 131, 2004.

Fennel, K., Follows, M., and Falkowski, P. G.: The co-evolution of the nitrogen, carbon and oxygen cycles in the Proterozoic ocean, Am. J. Sci., 305, 526-545, 2005.

Geider, R. J. and La Roche, J.: Redfield revisited: variability of $\mathrm{C}: \mathrm{N}: \mathrm{P}$ in marine microalgae and its biochemical basis, Eur. J. Phycol., 37, 1-17, 2002.

Goldman, J. C.: On phytoplankton growth rates and particulate $\mathrm{C}: \mathrm{N}: \mathrm{P}$ ratios at low light, Limnol. Oceanogr., 31, 1358-1361, 1986.

Goldman, J. C., McCarthy, J. J., and Peavey, D. G.: Growth rate influence on the chemical composition of phytoplankton in oceanic waters, Nature, 279, 210-215, 1979.

Handoh, I. C. and Lenton, T. M.: Periodic mid-Cretaceous Oceanic Anoxic Events linked by oscillations of the phosphorus and oxygen biogeochemical cycles, Global Biogeochem. Cy., 17, 1092, doi:10.1029/2003GB002039, 2003.

Hood, R. R., Coles, V. J., and Capone, D. G.: Modeling the distribution of Trichodesmium and nitrogen fixation in the Atlantic Ocean, J. Geophys. Res., 109, 1-25, 2004.

Karl, D. M., Letelier, R., Hebel, D. V., Bird, D. F., and Winn, C. D.: Trichodesmium blooms and new nitrogen in the North Pacific Gyre, in: Marine Pelagic Cyanobacteria: Trichodesmium and Other Diazotrophs, edited by: Carpenter, E. J., Kluwer Academic Publishers, pp. 219-237, 1992.

Klausmeier, C. A., Litchman, E., Daufresne, T., and Levin, S. A.: Optimal nitrogen-to-phosphorus stoichiometry of phytoplankton, Nature, 429, 171-174, 2004.

Kuypers, M. M. M., Sliekers, A. O., Lavik, G., Schmid, M., Jorgensen, B. B., Kuenen, J. G., Sinninghe Damste, J. S., Strous, M., and Jetten, M. S. M.: Anaerobic ammonium oxidation by anammox bacteria in the Black Sea, Nature, 422, 608-611, 2003.
Kuypers, M. M. M., van Breugel, Y., Schouten, S., Erba, E., and Sinninghe Damste, J. S.: $\mathrm{N}_{2}$-fixing cyanobacteria supplied nutrient $\mathrm{N}$ for Cretaceous oceanic anoxic events, Geology, 32, 853856, 2004.

Lenton, T. M.: The role of land plants, phosphorus weathering and fire in the rise and regulation of atmospheric oxygen, Glob. Change Biol., 7, 613-629, 2001.

Lenton, T. M. and Watson, A. J.: Redfield revisited: 1. Regulation of nitrate, phosphate and oxygen in the ocean, Global Biogeochem. Cy., 14, 225-248, 2000.

Lenton, T. M. and Watson, A. J.: Biotic enhancement of weathering, atmospheric oxygen and carbon dioxide in the Neoproterozoic, Geophys. Res. Lett., 31, L05202, doi:10.1029/2003GL018802, 2004.

Mills, M. M., Ridame, C., Davey, M., La Roche, J., and Geider, R. J.: Iron and phosphorus co-limit nitrogen fixation in the eastern tropical North Atlantic, Nature, 429, 292-294, 2004.

Piper, D. Z. and Codispoti, L. A.: Marine Phosphorite Deposits and the Nitrogen Cycle, Science, 188, 15-18, 1975.

Quigg, A., Finkel, Z. V., Irwin, A. J., Rosenthal, Y., Ho, T.-Y., Reinfelder, J. R., Schofield, O., Morel, F. M. M., and Falkowski, P. G.: The evolutionary inheritance of elemental stoichiometry in marine phytoplankton, Nature, 425, 291-294, 2003.

Redfield, A. C.: On the proportions of organic derivatives in sea water and their relation to the composition of plankton, James Johnstone Memorial Volume, University of Liverpool, Liverpool, pp. 176-192, 1934.

Redfield, A. C.: The biological control of chemical factors in the environment, Am. Sci., 46, 205-221, 1958.

Ruttenberg, K. C.: Reassessment of the oceanic residence time of phosphorus, Chem. Geol., 107, 405-409, 1993.

Sañudo-Wilhelmy, S. A., Kustka, A. B., Gobler, C. J., Hutchins, D. A., Yang, M., Lwiza, K., Burns, J., Capone, D. G., Raven, J. A., and Carpenter, E. J.: Phosphorus limitation of nitrogen fixation by Trichodesmium in the central Atlantic Ocean, Nature, 411, 66-69, 2001.

Schade, J. D., Espelata, J. F., Klausmeier, C. A., McGroddy, M. E., Thomas, S. A., and Zhang, L.: A conceptual framework for ecosystem stoichiometry: balancing resource supply and demand, Oikos, 109, 40-51, 2005.

Schulz, H. N. and Schulz, H. D.: Large Sulfur Bacteria and the Formation of Phosphorite, Science, 307, 416-418, 2005.

Tyrrell, T.: The relative influences of nitrogen and phosphorus on oceanic primary production, Nature, 400, 525-531, 1999.

Van Cappellen, P. and Ingall, E. D.: Redox stabilisation of the atmosphere and oceans by phosphorus-limited marine productivity, Science, 271, 493-496, 1996.

Wallmann, K.: Feedbacks between oceanic redox states and marine productivity: A model perspective focused on benthic phosphorus cycling, Global Biogeochem. Cy., 17, 1084, doi:10.1029/2002GB001968, 2003. 